Review

\title{
About Helicopters
}

\author{
${ }^{1}$ Relly Victoria Petrescu, ${ }^{2}$ Raffaella Aversa, ${ }^{3}$ Bilal Akash, ${ }^{4}$ Juan Corchado, \\ ${ }^{2}$ Antonio Apicella and ${ }^{1}$ Florian Ion Tiberiu Petrescu \\ ${ }^{1}$ ARoTMM-IFToMM, Bucharest Polytechnic University, Bucharest, (CE), Romania \\ ${ }^{2}$ Advanced Material Lab, Department of Architecture and Industrial Design, \\ Second University of Naples, 81031 Aversa (CE), Italy \\ ${ }^{3}$ Dean of School of Graduate Studies and Research, American University of Ras Al Khaimah, UAE \\ ${ }^{4}$ University of Salamanca, Spain
}

Article history

Received: 09-07-2017

Revised: 10-07-2017

Accepted: 09-09-2017

Corresponding Author: Florian Ion Tiberiu Petrescu ARoTMM-IFToMM, Bucharest Polytechnic University, Bucharest, (CE), Romania E-mail: scipub02@gmail.com
Abstract: A helicopter is a type of rotorcraft in which lift and thrust are supplied by one or more engine-driven rotors. In contrast with fixedwing aircraft, this allows the helicopter to take off and land vertically, to hover and to fly forwards, backward and laterally. These attributes allow helicopters to be used in congested or isolated areas where fixedwing aircraft would not be able to take off or land. The capability to efficiently hover for extended periods of time allows a helicopter to accomplish tasks that fixed-wing aircraft and other forms of vertical takeoff and landing aircraft cannot perform. The word 'helicopter' is adapted from the French hélicoptère, coined by Gustave de Ponton d'Amecourt in 1861, which originates from the Greek helix/helik = "twisted, curved" and pteron = "wing". Helicopters were developed and built during the first half-century of flight, with the Focke-Wulf Fw 61 being the first operational helicopter in 1936. Some helicopters reached limited production, but it was not until 1942 that a helicopter designed by Igor Sikorsky reached full-scale production, with 131 aircraft built. Though most earlier designs used more than one main rotor, it was the single main rotor with antitorque tail rotor configuration of this design that would come to be recognized worldwide as the helicopter. The earliest references for vertical flight have come from China. Since around $400 \mathrm{BC}$, Chinese children have played with bamboo flying toys and the 4th-century AD Daoist book Baopuzi ("Master who Embraces Simplicity") reportedly describes some of the ideas inherent to rotary wing aircraft: Someone asked the master about the principles of mounting to dangerous heights and traveling into the vast inane. The Master said, "Some have made flying cars with wood from the inner part of the jujube tree, using ox-leather fastened to returning blades so as to set the machine in motion." It was not until the early 1480s when Leonardo da Vinci created a design for a machine that could be described as an "aerial screw" that any recorded advancement was made towards vertical flight. His notes suggested that he built small flying models, but there were no indications for any provision to stop the rotor from making the whole craft rotate. As scientific knowledge increased and became more accepted, men continued to pursue the idea of vertical flight. Many of these later models and machines would more closely resemble the ancient bamboo flying top with spinning wings, rather than Da Vinci's screw.

Keywords: Helicopters, Aerospace, Spacecraft Propulsion, US Army, Jet Engines, Spirit Strategic Bomber, Defense Contractor 


\section{Introduction}

A helicopter is a type of rotorcraft in which lift and thrust are supplied by one or more engine-driven rotors. In contrast with fixed-wing aircraft, this allows the helicopter to take off and land vertically, to hover and to fly forwards, backward and laterally. These attributes allow helicopters to be used in congested or isolated areas where fixed-wing aircraft would not be able to take off or land. The capability to efficiently hover for extended periods of time allows a helicopter to accomplish tasks that fixed-wing aircraft and other forms of vertical takeoff and landing aircraft cannot perform.

The word 'helicopter' is adapted from the French hélicoptère, coined by Gustave de Ponton d'Amecourt in 1861 , which originates from the Greek helix/helik = "twisted, curved" and pteron = "wing".

Helicopters were developed and built during the first half-century of flight, with the Focke-Wulf Fw 61 being the first operational helicopter in 1936. Some helicopters reached limited production, but it was not until 1942 that a helicopter designed by Igor Sikorsky reached full-scale production, with 131 aircraft built. Though most earlier designs used more than one main rotor, it was the single main rotor with antitorque tail rotor configuration of this design that would come to be recognized worldwide as the helicopter (Petrescu and Petrescu, 2009; 2011; 2012a; 2012b; 2013a; 2013b; 2013c).

The earliest references for vertical flight have come from China. Since around $400 \mathrm{BC}$, Chinese children have played with bamboo flying toys and the 4th-century AD Daoist book Baopuzi ("Master who Embraces Simplicity") reportedly describes some of the ideas inherent to rotary wing aircraft.

Someone asked the master about the principles of mounting to dangerous heights and traveling into the vast inane. The Master said, "Some have made flying cars with wood from the inner part of the jujube tree, using ox-leather fastened to returning blades so as to set the machine in motion."

It was not until the early 1480 s when Leonardo da Vinci created a design for a machine that could be described as an "aerial screw" (Fig. 1), that any recorded advancement was made towards vertical flight. His notes suggested that he built small flying models, but there were no indications for any provision to stop the rotor from making the whole craft rotate. As scientific knowledge increased and became more accepted, men continued to pursue the idea of vertical flight. Many of these later models and machines would more closely resemble the ancient bamboo flying top with spinning wings, rather than Da Vinci's screw.

In July 1754, Mikhail Lomonosov demonstrated a small tandem rotor to the Russian Academy of Sciences. It was powered by a spring and suggested as a method to lift meteorological instruments. In 1783, Christian de
Launoy and his mechanic, Bienvenu, made a model with a pair of counter-rotating rotors, using turkey flight feathers as rotor blades and in 1784, demonstrated it to the French Academy of Sciences. Sir George Cayley, influenced by a childhood fascination with the Chinese flying top, grew up to develop a model of feathers, similar to Launoy and Bienvenu but powered by rubber bands. By the end of the century, he had progressed to using sheets of tin for rotor blades and springs for power. His writings on his experiments and models would become influential on future aviation pioneers. Alphonse Pénaud would later develop coaxial rotor model helicopter toys in 1870 , also powered by rubber bands. One of these toys, given as a gift by their father, would inspire the Wright brothers to pursue the dream of flight.

In 1861, the word "helicopter" was coined by Gustave de Ponton D'Amécourt, a French inventor who demonstrated a small, steam-powered model. While celebrated as an innovative use of a new metal, aluminum, the model never lifted off the ground. D'Amecourt's linguistic contribution would survive to eventually describe the vertical flight he had envisioned. Steam power was popular with other inventors as well. In 1878 Enrico Forlanini's unmanned helicopter was also powered by a steam engine. It was the first of its type that rose to a height of $12 \mathrm{~m}(40 \mathrm{ft})$, where it hovered for some $20 \mathrm{sec}$ after a vertical take-off. Emmanuel Dieuaide's steampowered design featured counter-rotating rotors powered through a hose from a boiler on the ground.

In 1885 , Thomas Edison was given US $\$ 1,000$ by James Gordon Bennett, Jr., to conduct experiments towards developing flight. Edison built a helicopter and used the paper for a stock ticker to create guncotton, with which he attempted to power an internal combustion engine. The helicopter was damaged by explosions and one of his workers was badly burned. Edison reported that it would take a motor with a ratio of three to four pounds per horsepower produced to be successful, based on his experiments. Ján Bahýl, a Slovak inventor, adapted the internal combustion engine to power his helicopter model that reached a height of $0.5 \mathrm{~m}(1.6 \mathrm{ft})$ in 1901. On 5 May 1905, his helicopter reached four $\mathrm{m}(13$ $\mathrm{ft})$ in altitude and flew for over $1,500 \mathrm{~m}(4,900 \mathrm{ft})$. In 1908, Edison patented his own design for a helicopter powered by a gasoline engine with box kites attached to a mast by cables for a rotor, but it never flew.

In 1906, two French brothers, Jacques and Louis Breguet, began experimenting with airfoils for helicopters and in 1907, those experiments resulted in the Gyroplane No.1. Although there is some uncertainty about the dates, sometime between 14 August and 29 September 1907, the Gyroplane No. 1 lifted its pilot up into the air about two feet $(0.6 \mathrm{~m})$ for a minute. However, the Gyroplane No. 1 proved to be extremely unsteady and required a man at each corner of the airframe to hold it steady. For this reason, the flights of the Gyroplane No. 1 are considered to be the first manned flight of a helicopter, but not a free or untethered flight. 

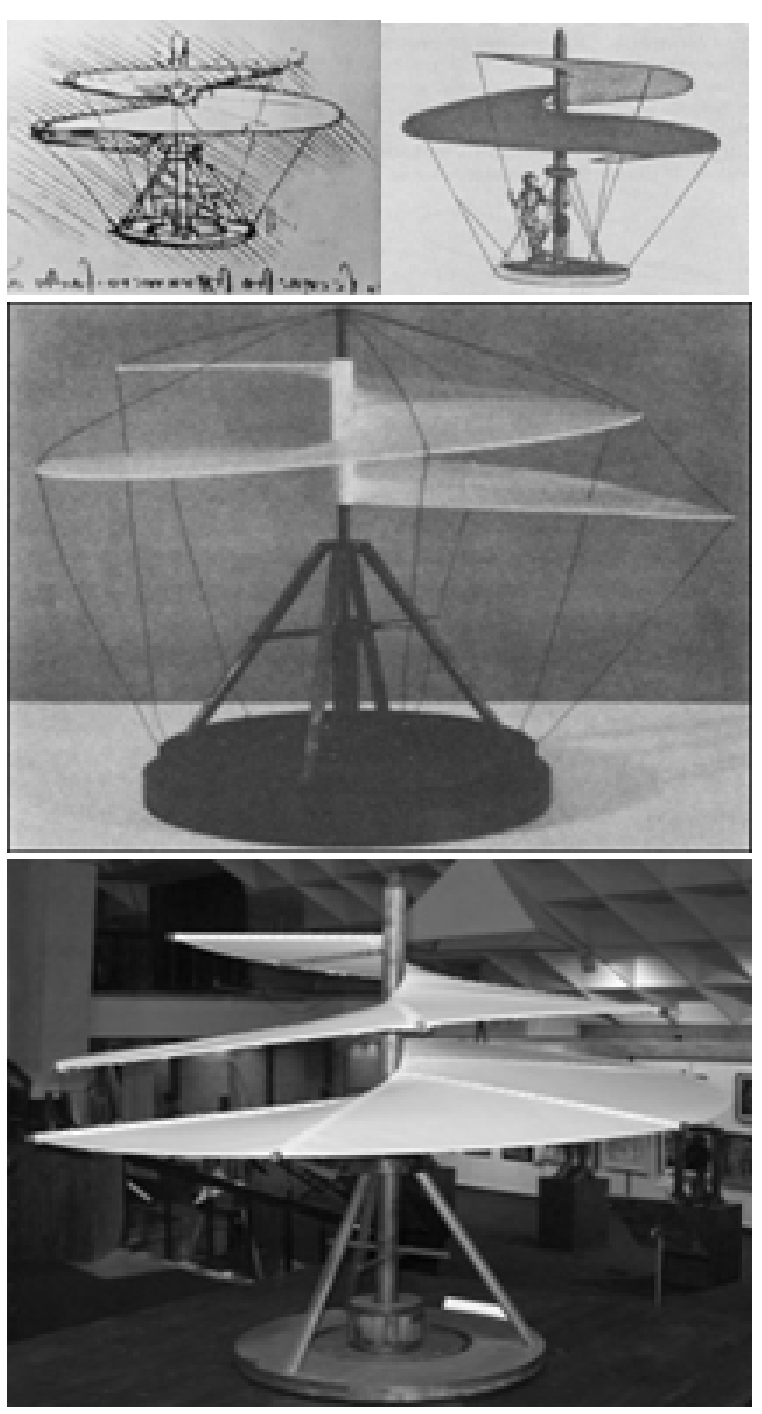

Fig. 1. First helicopter designed by Leonardo da Vinci (1480). Source: Petrescu and Petrescu (2011)

That same year, fellow French inventor Paul Cornu (Romanian-born French) designed and built a Cornu helicopter that used two 20 -foot $(6 \mathrm{~m})$ counter-rotating rotors driven by a 24-hp (18-kW) Antoinette engine (Fig. 2). On 13 November 1907, it lifted its inventor to 1 foot $(0.3 \mathrm{~m})$ and remained aloft for $20 \mathrm{sec}$. Even though this flight did not surpass the flight of the Gyroplane No. 1, it was reported to be the first truly free flight with a pilot. Cornu's helicopter would complete a few more flights and achieve a height of nearly 6.5 feet $(2 \mathrm{~m})$, but it proved to be unstable and was abandoned.

The Danish inventor Jacob Ellehammer built the Ellehammer helicopter in 1912. It consisted of a frame equipped with two contra-rotating discs, each of which was fitted with six vanes around its circumference. After a number of indoor tests, the aircraft was demonstrated outdoors and made a number of free take-offs. Experiments with the helicopter continued until September 1916, when it tipped over during take-off, destroying its rotors.

In the early 1920s, Argentine Raúl Pateras Pescara, while working in Europe, demonstrated one of the first successful applications of cyclic pitch. Coaxial, contrarotating, biplane rotors could be warped to cyclically increase and decrease the lift they produced. The rotor hub could also be tilted forward a few degrees, allowing the aircraft to move forward without a separate propeller to push or pull it. Pescara was also able to demonstrate the principle of autorotation, by which helicopters safely land after engine failure. By January 1924, Pescara's helicopter No. 3 could fly for up to ten min.

One of Pescara's contemporaries, Frenchman Etienne Oehmichen, set the first helicopter world record recognized by the Fédération Aéronautique Internationale (FAI) on 14 April 1924, flying his helicopter $360 \mathrm{~m}$ (1,181 ft), (Fig. 3). On 18 April 1924, Pescara beat Oemichen's record, flying for a distance of $736 \mathrm{~m}$ (nearly a half mile) in $4 \mathrm{~min}$ and $11 \mathrm{sec}$ (about $8 \mathrm{mph}, 13 \mathrm{~km} / \mathrm{h}$ ) maintaining a height of six feet $(2 \mathrm{~m})$. Not to be outdone, Oehmichen reclaimed the world record on 4 May when he flew his No. 2 machine again for a 14-min flight covering 5,550 feet $(1.05 \mathrm{mi}, 1.69 \mathrm{~km})$ while climbing to a height of 50 feet $(15 \mathrm{~m})$. Oehmichen also set the $1 \mathrm{~km}$ closedcircuit record at $7 \mathrm{~min} 40 \mathrm{sec}$.

In the USA, George de Bothezat built the quadrotor De Bothezat helicopter for the United States Army Air Service but the Army canceled the program in 1924 and the aircraft was scrapped.

Meanwhile, Juan de la Cierva was developing the first practical rotorcraft in Spain. In 1923, the aircraft that would become the basis for the modern helicopter rotor began to take shape in the form of an autogyro, Cierva's C.4. Cierva had discovered aerodynamic and structural deficiencies in his early designs that could cause his autogyros to flip over after takeoff. The flapping hinges that Cierva designed for the C.4 allowed the rotor to develop lift equally on the left and right halves of the rotor disk. A crash in 1927, led to the development of a drag hinge to relieve further stress on the rotor from its flapping motion. These two developments allowed for a stable rotor system, not only in a hover but in forwarding flight.

Albert Gillis von Baumhauer, a Dutch aeronautical engineer, began studying rotorcraft design in 1923. His first prototype "flew" ("hopped" and hovered in reality) on 24 September 1925, with Dutch Army-Air arm Captain Floris Albert van Heijst at the controls. The controls that Captain van Heijst used were Von Baumhauer's inventions, the cyclic and collective. Patents were granted to von Baumhauer for his cyclic and collective controls by the British Ministry of Aviation on 31 January 1927, under patent number 265,272. 


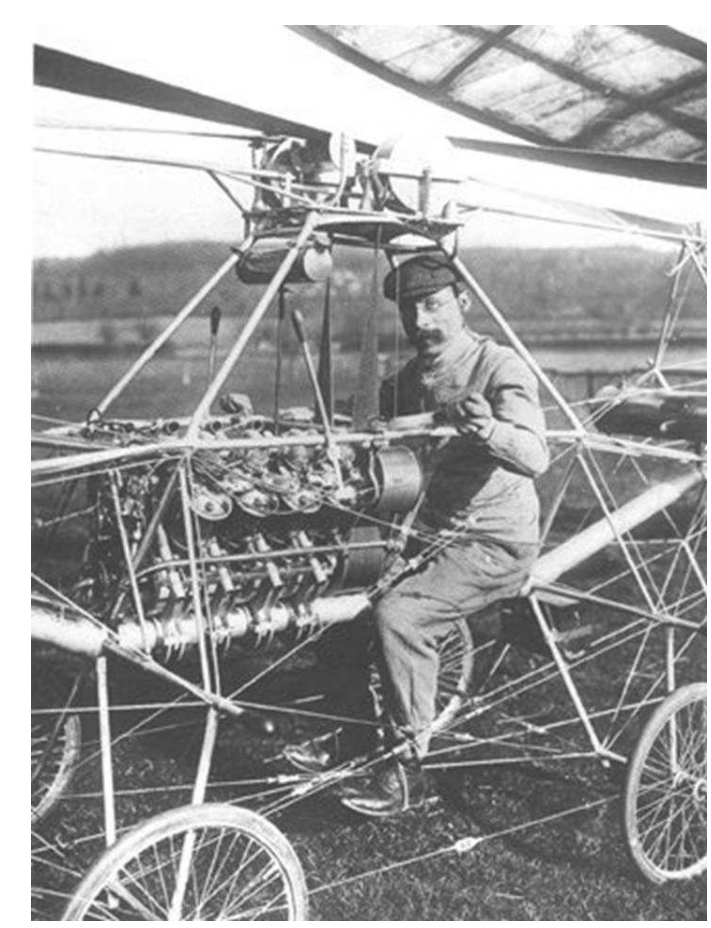

Fig. 2. The first helicopter made by the French inventor Paul Cornu (1907). Source: Petrescu and Petrescu (2011)

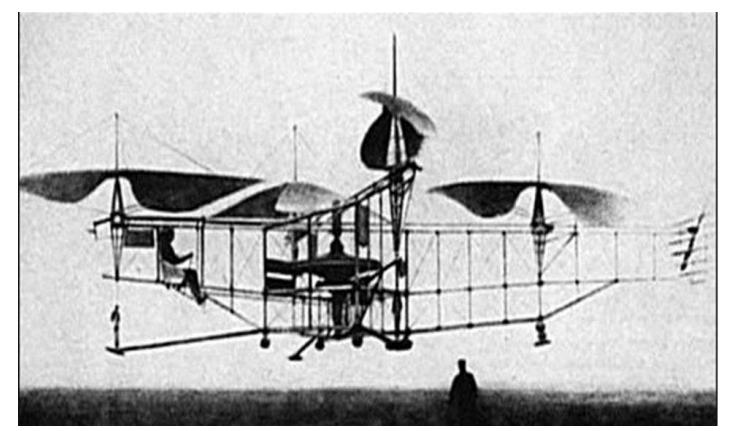

Fig. 3. A helicopter made by the Frenchman Etienne Oehmichen (1922). Source: Petrescu and Petrescu (2011)

In 1928, Hungarian aviation engineer Oszkár Asbóth constructed a helicopter prototype that took off and landed at least 182 times, with a maximum single flight duration of $53 \mathrm{~min}$.

In 1930, the Italian engineer Corradino D'Ascanio built his D'AT3, a coaxial helicopter. His relatively large machine had two, two-bladed, counter-rotating rotors. Control was achieved by using auxiliary wings or servotabs on the trailing edges of the blades, a concept that was later adopted by other helicopter designers, including Bleeker and Kaman. Three small propellers mounted to the airframe were used for additional pitch, roll and yaw control. The D'AT3 held modest FAI speed and altitude records for the time, including altitude $(18 \mathrm{~m}$ or $59 \mathrm{ft}$ ), duration ( $8 \mathrm{~min} 45 \mathrm{sec}$ ) and distance flew $(1,078 \mathrm{~m}$ or $3,540 \mathrm{ft})$.
In the Soviet Union, Boris N. Yuriev and Alexei M. Cheremukhin, two aeronautical engineers working at the Tsentralniy Aerogidrodinamicheskiy Institut (English: Central Aerohydrodynamic Institute), constructed and flew the TsAGI 1-EA single rotor helicopter, which used an open tubing framework, a four-blade main rotor and twin sets of $1.8 \mathrm{~m}$ (6-foot) diameter anti-torque rotors; one set of two at the nose and one set of two at the tail. Powered by two M-2 powerplants, up-rated copies of the Gnome Monosoupape rotary radial engine of World War I, the TsAGI 1-EA made several successful low altitude flights. By 14 August 1932, Cheremukhin managed to get the 1-EA up to an unofficial altitude of $605 \mathrm{~m} \mathrm{(1,985}$ $\mathrm{ft}$ ), shattering d'Ascanio's earlier achievement. As the Soviet Union was not yet a member of the FAI, however, Cheremukhin's record remained unrecognized.

Nicolas Florine, a Russian engineer, built the first twin tandem rotor machine to perform a free flight. It flew in Sint-Genesius-Rode, at the Laboratoire Aérotechnique de Belgique (now von Karman Institute) in April 1933 and attained an altitude of six m (20 ft) and an endurance of eight min. Florine chose a co-rotating configuration because the gyroscopic stability of the rotors would not cancel. Therefore the rotors had to be tilted slightly in opposite directions to counter torque. Using hingeless rotors and co-rotation also minimized the stress on the hull. At the time, it was one of the most stable helicopters in existence.

The Bréguet-Dorand Gyroplane Laboratoire was built in 1933. After many ground tests and an accident, it first took flight on 26 June 1935. Within a short time, the aircraft was setting records with pilot Maurice Claisse at the controls. On 14 December 1935, he set a record for closed-circuit flight with a $500 \mathrm{~m}(1,600 \mathrm{ft})$ diameter. The next year, on 26 September 1936, Claisse set a height record of $158 \mathrm{~m}(520 \mathrm{ft})$. And, finally, on 24 November 1936, he set a flight duration record of one h, two min and $5 \mathrm{sec}$ over a $44 \mathrm{~km}(27 \mathrm{mi})$ closed circuit at $44.7 \mathrm{~km}$ per $\mathrm{h}(27.8 \mathrm{mph})$. The aircraft was destroyed in 1943 by an Allied airstrike at Villacoublay airport.

Despite the success of the Gyroplane Laboratoire, the German Focke-Wulf Fw 61, first flown in 1936, would eclipse its accomplishments. The Fw 61 broke all of the helicopter world records in 1937, demonstrating a flight envelope that had only previously been achieved by the autogyro. Nazi Germany would use helicopters in small numbers during World War II for observation, transport and medical evacuation. The Flettner Fl 282 Kolibri synchropter was used in the Mediterranean, while the Focke Achgelis Fa 223 Drache was used in Europe. Extensive bombing by the Allied forces prevented Germany from producing any helicopters in large quantities during the war. 
In the United States, Igor Sikorsky and W. Lawrence LePage were competing to produce the United States military's first helicopter. Prior to the war, LePage had received the patent rights to develop helicopters patterned after the FW 61 and built the XR-1. Meanwhile, Sikorsky had settled on a simpler, single rotor design, the VS-300. After experimenting with configurations to counteract the torque produced by the single main rotor, he settled on a single, smaller rotor mounted vertically on the tail boom.

Developed from the VS-300, Sikorsky's R-4 became the first mass-produced helicopter with a production order for 100 aircraft. The R-4 was the only Allied helicopter to see service in World War II, primarily being used for rescue in Burma, Alaska and other areas with harsh terrain. Total production would reach 131 helicopters before the R-4 was replaced by other Sikorsky helicopters such as the R-5 and the R-6. In all, Sikorsky would produce over 400 helicopters before the end of World War II.

As LePage and Sikorsky were building their helicopters for the military, Bell Aircraft hired Arthur Young to help build a helicopter using Young's two-blade teetering rotor design which used a weighted stabilizing bar placed at a $90^{\circ}$ angle to the rotor blades. The subsequent Model 30 helicopter showed the design's simplicity and ease of use. The Model 30 was developed into the Bell 47, which became the first helicopter certificated for civilian use in the United States. Produced in several countries, the Bell 47 would stand as the most popular helicopter model for nearly 30 years (Fig. 4).

In 1951, at the urging of his contacts at the Department of the Navy, Charles Kaman modified his K-225 helicopter with a new kind of engine, the turboshaft engine. This adaptation of the turbine engine provided a large amount of power to the helicopter with a lower weight penalty than piston engines, with their heavy engine blocks and auxiliary components. On 11 December 1951, the Kaman K-225 became the first turbine-powered helicopter in the world. Two years later, on 26 March 1954, a modified Navy HTK-1, another Kaman helicopter, became the first twin-turbine helicopter to fly. However, it was the Sud Aviation Alouette II that would become the first helicopter to be produced with a turbine-engine.

Reliable helicopters capable of stable hover flight were developed decades after fixed-wing aircraft. This is largely due to higher engine power density requirements than fixed-wing aircraft. Improvements in fuels and engines during the first half of the $20^{\text {th }}$ century were a critical factor in helicopter development. The availability of lightweight turboshaft engines in the second half of the $20^{\text {th }}$ century led to the development of larger, faster and higher-performance helicopters. While smaller and less expensive helicopters still use piston engines, turboshaft engines are the preferred power plant for helicopters today.

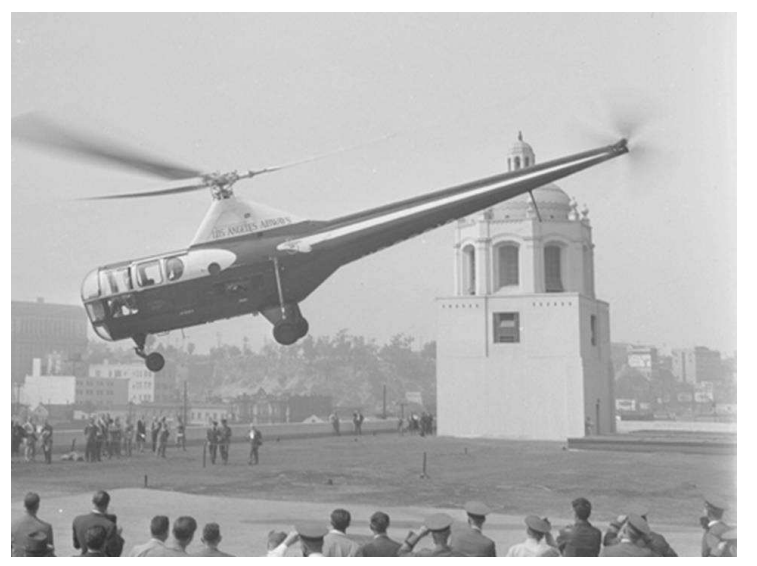

Fig. 4. First modern helicopter made by Igor Sikorsky (1947). Source: Petrescu and Petrescu (2011)

Due to the operating characteristics of the helicopterits ability to take off and land vertically and to hover for extended periods of time, as well as the aircraft's handling properties under low airspeed conditions-it has been chosen to conduct tasks that were previously not possible with other aircraft, or were time- or workintensive to accomplish on the ground. Today, helicopter uses include transportation, construction, firefighting, search and rescue and military uses.

A helicopter used to carry loads connected to long cables or slings is called an aerial crane. Aerial cranes are used to place heavy equipment, like radio transmission towers and large air conditioning units, on the tops of tall buildings, or when an item must be raised up in a remote area, such as a radio tower raised on the top of a hill or mountain. Helicopters are used as aerial cranes in the logging industry to lift trees out of terrain where vehicles cannot travel and where environmental concerns prohibit the building of roads. These operations are referred to as longline because of the long, single sling line used to carry the load.

Helitack is the use of helicopters to combat wildland fires. The helicopters are used for aerial firefighting (or water bombing) and may be fitted with tanks or carry held buckets. Helibuckets, such as the Bambi bucket, are usually filled by submerging the bucket into lakes, rivers, reservoirs, or portable tanks. Tanks fitted onto helicopters are filled from a hose while the helicopter is on the ground or water is siphoned from lakes or reservoirs through a hanging snorkel as the helicopter hovers over the water source. Helitack helicopters are also used to deliver firefighters, who rappel down to inaccessible areas and to resupply firefighters. Common firefighting helicopters include variants of the Bell 205 and the Erickson S-64 Aircrane Helitanker.

\section{Materials and Methods}

Helicopters are used as air ambulances for emergency medical assistance in situations when an ambulance cannot 
easily or quickly reach the scene. Helicopters are also used when a patient needs to be transported between medical facilities and air transportation is the most practical method for the safety of the patient. Air ambulance helicopters are equipped to provide medical treatment to a patient while in flight. The use of helicopters as an air ambulance is often referred to as MEDEVAC and patients are referred to as being "airlifted", or "medevacked".

Police departments and other law enforcement agencies use helicopters to pursue suspects. Since helicopters can achieve a unique aerial view, they are often used in conjunction with police on the ground to report on suspects' locations and movements. They are often mounted with lighting and heat-sensing equipment for night pursuits.

Military forces use attack helicopters to conduct aerial attacks on ground targets. Such helicopters are mounted with missile launchers and miniguns. Transport helicopters are used to ferry troops and supplies where the lack of an airstrip would make transport via fixedwing aircraft impossible. The use of transport helicopters to deliver troops as an attack force on an objective is referred to as Air Assault. Unmanned Aerial Systems (UAS) helicopter systems of varying sizes are being developed by companies for military reconnaissance and surveillance duties. Naval forces also use helicopters equipped with dipping sonar for anti-submarine warfare, since they can operate from small ships.

Oil companies charter helicopters to move workers and parts quickly to remote drilling sites located out to sea or in remote locations. The speed over boats makes the high operating cost of helicopters cost effective to ensure that oil platforms continue to flow. Various companies specialize in this type of operation.

The rotor system, or more simply rotor, is the rotating part of a helicopter which generates lift. A rotor system may be mounted horizontally as main rotors are, providing lift vertically, or it may be mounted vertically, such as a tail rotor, to provide lift horizontally as thrust to counteract torque effect. The rotor consists of a mast, hub and rotor blades.

The mast is a cylindrical metal shaft which extends upwards from and is driven by the transmission. At the top of the mast is the attachment point for the rotor blades called the hub. The rotor blades are then attached to the hub by a number of different methods. Main rotor systems are classified according to how the main rotor blades are attached and move relative to the main rotor hub. There are three basic classifications: Hingeless, fully articulated and teetering, although some modern rotor systems use an engineered combination of these types.

Most helicopters have a single main rotor, but torque created as the engine turns the rotor against its air drag causes the body of the helicopter to turn in the opposite direction to the rotor. To eliminate this effect, some sort of antitorque control must be used. The design that Igor Sikorsky settled on for his VS-300 was a smaller rotor mounted vertically on the tail. The tail rotor pushes or pulls against the tail to counter the torque effect and has become the recognized convention for helicopter design. Some helicopters utilize alternate antitorque controls in place of the tail rotor, such as the ducted fan (called Fenestron or FANTAIL) and NOTAR. NOTAR provides antitorque similar to the way a wing develops lift, through the use of a Coandă effect on the tail boom (Fig. 5).

The use of two or more horizontal rotors turning in opposite directions is another configuration used to counteract the effects of torque on the aircraft without relying on an antitorque tail rotor.

This allows the power normally required to drive the tail rotor to be applied to the main rotors, increasing the aircraft's lifting capacity.

Primarily, there are three common configurations that use the counterrotating effect to benefit the rotorcraft.

Tandem rotors are two rotors with one mounted behind the other. Coaxial rotors are two rotors that are mounted one above the other with the same axis. Intermeshing rotors are two rotors that are mounted close to each other at a sufficient angle to allow the rotors to intermesh over the top of the aircraft (Mirsayar et al., 2017).

Transverse rotors is another configuration found on tilt rotors and some earlier helicopters, where the pair of rotors are mounted at each end of the wings or outrigger structures (Aversa et al., 2016a; 2016b; 2016c; 2016d; 2016e; 2016f; 2016g; 2016h; 2016i; 2016j; 2016k; 20161; 2016m; 2016n; 2016o; 2017a; 2017b; 2017c; 2017d; 2017e).

Tip jet designs permit the rotor to push itself through the air and avoid generating torque (Fig. 6).

The number, size and type of engine used on a helicopter determines the size, function and capability of that helicopter design. The earliest helicopter engines were simple mechanical devices, such as rubber bands or spindles, which relegated the size of helicopters to toys and small models. For a half century before the first airplane flight, steam engines were used to forward the development of the understanding of helicopter aerodynamics, but the limited power did not allow for manned flight. The introduction of the internal combustion engine at the end of the 19th century became the watershed for helicopter development as engines began to be developed and produced that were powerful enough to allow for helicopters able to lift humans.

Early helicopter designs utilized custom-built engines or rotary engines designed for airplanes, but these were soon replaced by more powerful automobile engines and radial engines. The single, most limiting factor of helicopter development during the first half of the $20^{\text {th }}$ century was that the amount of power produced by an engine was not able to overcome the engine's weight in vertical flight. This was overcome in early successful helicopters by using the smallest engines available. When the compact, flat engine was developed, the helicopter industry found a lighter-weight powerplant easily adapted to small helicopters, although radial engines continued to be used for larger helicopters. 


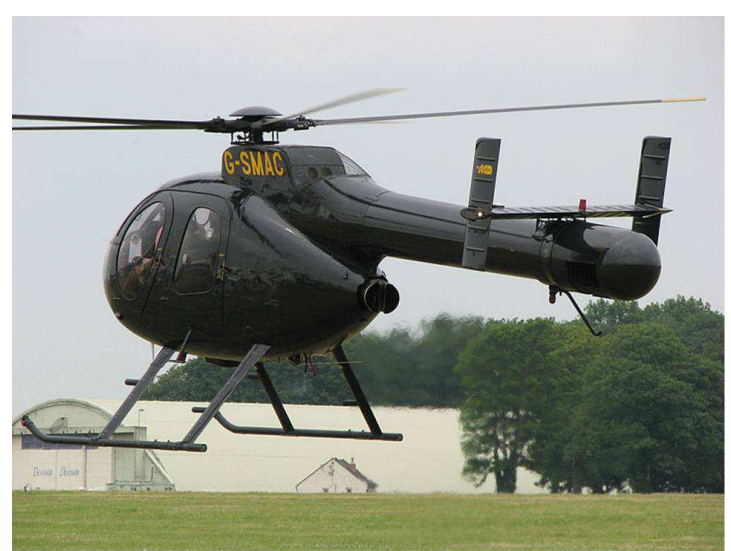

Fig. 5. MD helicopters $520 \mathrm{~N}$ NOTAR. Source: Petrescu and Petrescu (2011)

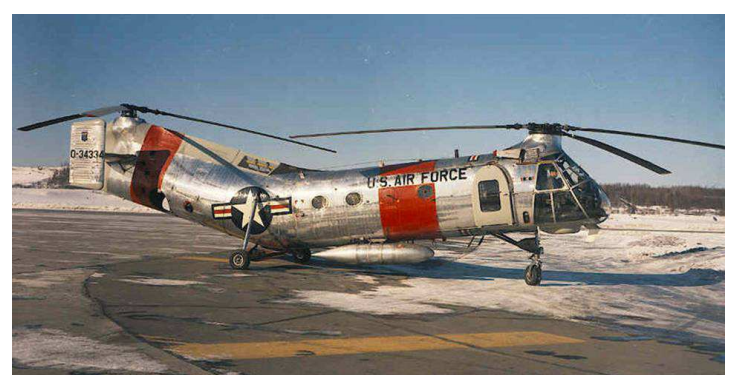

Fig. 6. The Piasecki H-21 employed tandem rotors. Source: Petrescu and Petrescu (2011)

Turbine engines revolutionized the aviation industry and the turboshaft engine finally gave helicopters an engine with a large amount of power and a low weight penalty. The turboshaft engine was able to be scaled to the size of the helicopter being designed so that all but the lightest of helicopter models are powered by turbine engines today.

Special jet engines developed to drive the rotor from the rotor tips are referred to as tip jets. Tip jets powered by a remote compressor are referred to as cold tip jets, while those powered by combustion exhaust are referred to as hot tip jets. An example of a cold jet helicopter is the Sud-Ouest Djinn and an example of the hot tip jet helicopter is the YH-32 Hornet.

Some radio-controlled helicopters and smaller, helicopter-type unmanned aerial vehicles, use electric motors. Radio-controlled helicopters may also have piston engines that use fuels other than gasoline, such as Nitromethane. Some turbine engines commonly used in helicopters can also use biodiesel instead of jet fuel.

A helicopter has four flight control inputs. These are the cyclic, the collective, the anti-torque pedals and the throttle. The cyclic control is usually located between the pilot's legs and is commonly called the cyclic stick or just cyclic on most helicopters, the cyclic is similar to a joystick. However, the Robinson $\mathrm{R}_{22}$ and Robinson $\mathrm{R}_{44}$ have a unique teetering bar cyclic control system and a few helicopters have a cyclic control that descends into the cockpit from overhead.

The control is called the cyclic because it changes the pitch of the rotor blades cyclically. The result is to tilt the rotor disk in a particular direction, resulting in the helicopter moving in that direction. If the pilot pushes the cyclic forward, the rotor disk tilts forward and the rotor produces a thrust in the forward direction. If the pilot pushes the cyclic to the side, the rotor disk tilts to that side and produces thrust in that direction, causing the helicopter to hover sideways.

The collective pitch control or collective is located on the left side of the pilot's seat with a settable friction control to prevent inadvertent movement. The collective changes the pitch angle of all the main rotor blades collectively (i.e., all at the same time) and independently of their position. Therefore, if a collective input is made, all the blades change equally and the result is the helicopter increasing or decreasing in altitude.

The anti-torque pedals are located in the same position as the rudder pedals in a fixed-wing aircraft and serve a similar purpose, namely to control the direction in which the nose of the aircraft is pointed. Application of the pedal in a given direction changes the pitch of the tail rotor blades, increasing or reducing the thrust produced by the tail rotor and causing the nose to yaw in the direction of the applied pedal. The pedals mechanically change the pitch of the tail rotor altering the amount of thrust produced.

Helicopter rotors are designed to operate in a narrow range of RPM. The throttle controls the power produced by the engine, which is connected to the rotor by a fixed ratio transmission. The purpose of the throttle is to maintain enough engine power to keep the rotor RPM within allowable limits in order to keep the rotor producing enough lift for flight. In single-engine helicopters, the throttle control is a motorcycle-style twist grip mounted on the collective control, while dualengine helicopters have a power lever for each engine.

A Swashplate transmits the pilot commands to the main rotor blades for articulated rotors.

There are three basic flight conditions for a helicopter; hover and forward flight and the transition between the two.

\section{Hover}

Hovering is the most challenging part of flying a helicopter. This is because a helicopter generates its own gusty air while in a hover, which acts against the fuselage and flight control surfaces. The end result is constant control inputs and corrections by the pilot to keep the helicopter where it is required to be. Despite the complexity of the task, the control inputs in a hover are simple. The cyclic is used to eliminate drift in the horizontal plane, that is to control forward and back, right and left. The collective is used to maintain altitude. The pedals are used to control nose direction or heading. It is the interaction of these 
controls that makes hovering so difficult, since an adjustment in any one control requires an adjustment of the other two, creating a cycle of constant correction.

\section{Transition from Hover to Forward Flights}

As a helicopter moves from hover to forward flight it enters a state called Translational lift which provides extra lift without increasing power. This state, most typically, occurs when the airspeed reaches approximately 16-24 knots and may be necessary for a helicopter to obtain flight.

\section{Forward Flight}

In forwarded flight, a helicopter's flight controls behave more like that in a fixed-wing aircraft. Displacing the cyclic forward will cause the nose to pitch down, with a resultant increase in airspeed and loss of altitude. Aft cyclic will cause the nose to pitch up, slowing the helicopter and causing it to climb. Increasing collective (power) while maintaining a constant airspeed will induce a climb while decreasing collective will cause a descent. Coordinating these two inputs, down collective plus aft cyclic or up collective plus forward cyclic, will result in airspeed changes while maintaining a constant altitude. The pedals serve the same function in both a helicopter and a fixed-wing aircraft, to maintain balanced flight. This is done by applying a pedal input in whichever direction is necessary to center the ball in the turn and bank indicator.

The main limitation of the helicopter is its low speed. There are several reasons a helicopter cannot fly as fast as a fixed-wing aircraft. When the helicopter is hovering, the outer tips of the rotor travel at a speed determined by the length of the blade and the RPM. In a moving helicopter, however, the speed of the blades relative to the air depends on the speed of the helicopter as well as on their rotational velocity.

The airspeed of the advancing rotor blade is much higher than that of the helicopter itself. It is possible for this blade to exceed the speed of sound and thus produce vastly increased drag and vibration. See Wave drag.

Because the advancing blade has higher airspeed than the retreating blade and generates a dissymmetry of lift, rotor blades are designed to "flap" - lift and twist in such a way that the advancing blade flaps up and develops a smaller angle of attack. Conversely, the retreating blade flaps down develops a higher angle of attack and generates more lift. At high speeds, the force on the rotors is such that they "flap" excessively and the retreating blade can reach too high an angle and stall. For this reason, the maximum safe forward airspeed of a helicopter is given a design rating called VNE, Velocity, Never Exceed.

In addition, it is possible for the helicopter to fly at an airspeed where an excessive amount of the retreating blade stalls which results in high vibration, pitch-up and roll into the retreating blade.
During the closing years of the $20^{\text {th }}$-century designers began working on helicopter noise reduction. Urban communities have often expressed great dislike of noisy aircraft and police and passenger helicopters can be unpopular.

The redesigns followed the closure of some city heliports and government action to constrain flight paths in national parks and other places of natural beauty.

Helicopters also vibrate; an unadjusted helicopter can easily vibrate so much that it will shake itself apart. To reduce vibration, all helicopters have rotor adjustments for height and weight. Blade height is adjusted by changing the pitch of the blade.

Weight is adjusted by adding or removing weights from the rotor head and/or at the blade end caps. Most also have vibration dampers for height and pitch. Some also use mechanical feedback systems to sense and counter vibration.

Usually, the feedback system uses a mass as a "stable reference" and a linkage from the mass operates a flap to adjust the rotor's angle of attack to counter the vibration. Adjustment is difficult in part because measurement of the vibration is hard, usually requiring sophisticated accelerometers mounted throughout the airframe and gearboxes.

The most common blade vibration adjustment measurement system is to use a stroboscopic flash lamp and observe painted markings or colored reflectors on the underside of the rotor blades. The traditional lowtech system is to mount colored chalk on the rotor tips and see how they mark a linen sheet. Gearbox vibration most often requires a gearbox overhaul or replacement. Gearbox or drive train vibrations can be extremely harmful to a pilot. The most severe being a pain, numbness, loss of tactile discrimination and dexterity.

\section{Canada Receives First CH-148 Maritime Helicopter}

The first interim maritime helicopter, the $\mathrm{CH}-148$ Cyclone, arrived at 12 Wing Shearwater, Nova Scotia, last week to support training of Canadian Forces (CF) aircrew and technicians for the Maritime Helicopter Project (Fig. 7).

"The arrival of this helicopter in Shearwater demonstrates progress with this project and brings us one step closer towards the delivery of a Maritime Helicopter capability that provides the Canadian Forces with a modern, flexible helicopter to assist in the defence of Canada and Canadian interests well into the future," said the Honourable Peter MacKay, Minister of National Defence.

On May 13, 2011, Sikorsky Operations International Inc. flew the helicopter to Shearwater as part of its contractual obligation under the Maritime Helicopter Project to deliver initial cadre training to the Canadian Forces. The helicopter will be used as a ground-based training aid for technicians. 


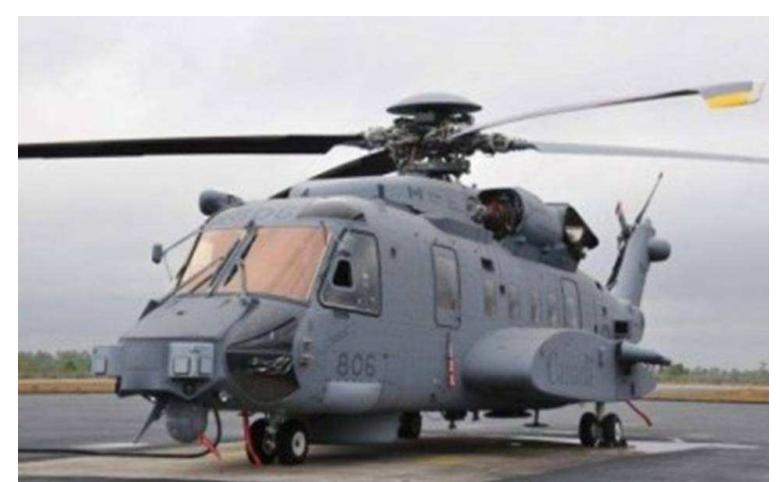

Fig. 7. CH-148 Cyclone. Source: Petrescu and Petrescu (2011)

The arrival of this helicopter does not mark formal delivery at this time as Sikorsky has not yet met all of the contractual delivery requirements. The helicopter will remain under Sikorsky title and control until all requirements are met.

The CF will take formal delivery and assume ownership of the helicopter once a Canadian military airworthiness certificate is granted and once initial aircrew flight training is conducted.

Sikorsky continues to make steady progress. Formal delivery of the first interim maritime helicopter is expected later this summer. The new Cyclone, in its final configuration, will be at the forefront of modern technology and will be one of the most capable maritime helicopters in the world.

The Agusta A129 Mangusta (English: Mongoose) is an attack helicopter originally designed and produced by Agusta in Italy (Fig. 8). It was the first attack helicopter to be designed and produced wholly in Western Europe. The TAI/Agusta Westland T-129 ATAK is an enhanced version of the A129 and its development is now the responsibility of Turkish Aerospace Industries (TAI), with Agusta Westland as the primary partner.

The Bell AH-1 Super Cobra is a twin-engine attack helicopter based on the US Army's AH-1 Cobra. The twin Cobra family includes the AH-1J Sea Cobra, the AH-1T Improved Sea Cobra and the AH-1W Super Cobra. The AH-1 W is the backbone of the United States Marine Corps's attack helicopter fleet but will be replaced in service by the Bell AH-1Z Viper upgrade in the next decade (Fig. 9).

The AH-1 Cobra was developed in the mid-1960s as an interim gunship for the U.S. Army for use in Vietnam. The Cobra shared the proven transmission, rotor system and the T 53 turboshaft engine of the UH-1 "Huey". By June 1967, the first AH-1G Huey Cobras had been delivered. Bell built 1,116 AH-1Gs for the U.S. Army between 1967 and 1973 and the Cobras chalked up over a million operational hours in Vietnam.

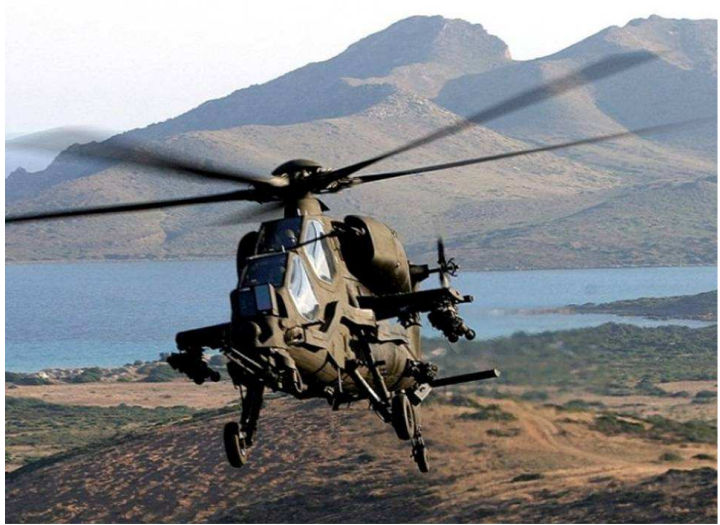

Fig. 8. Agusta A 129 Mangusta. Source: Petrescu and Petrescu (2011)

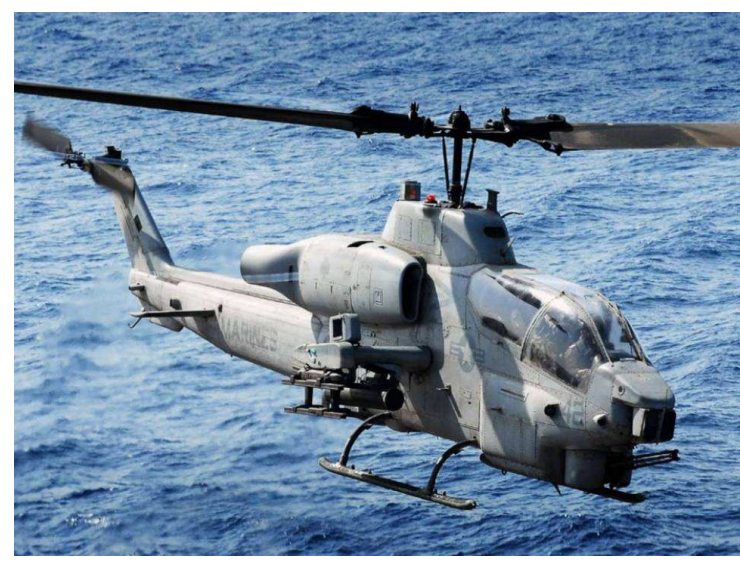

Fig. 9. The bell AH-1W super cobra is the backbone of the United States marine corps's attack helicopter fleet. Source: Petrescu and Petrescu (2011)

The U.S. Marine Corps was very interested in the AH1G Cobra but preferred a twin-engined version for improved safety in over-water operations and also wanted a more potent turret-mounted weapon. At first, the Department of Defense had balked at providing the Marines with a twin-engined version of the Cobra, in the belief that commonality with Army AH-1Gs outweighed the advantages of a different engine fit. However, the Marines won out and awarded Bell a contract for 49 twin-engined AH-1J Sea Cobras in May 1968. As an interim measure, the U.S. Army passed on 38 AH-1Gs to the Marines in 1969. The AH-1J also received a more powerful gun turret. It featured a three barrel $20 \mathrm{~mm}$ XM 197 cannon that was based on the six barrel M 61 Vulcan cannon.

The Marine Corps requested greater load carrying capability in high temperatures for the Cobra in the 1970s. Bell used systems from its Model 309 to develop the AH-1T. This version had a lengthened tail boom and fuselage with an upgraded transmission and engines from the 309. Bell designed the AH-1T to be more reliable and easier to maintain in the field. The version 
was given full TOW missile capability with a targeting system and other sensors. An advanced version, known as the AH-1T+ with more powerful T700-GE-700 engines and advanced avionics was proposed to Iran in the late 1970s, but the overthrow of the Shah of Iran resulted in the sale being canceled.

In the early 1980 s, the U.S. Marine Corps sought a new navalized helicopter but was denied funding to buy the AH-64 Apache by Congress in 1981. The Marines, in turn, pursued a more powerful version of the AH-1T. Other changes included modified fire control systems to carry and fire AIM-9 Sidewinder and AGM-114 Hellfire missiles. The new version was funded by Congress and received the $\mathrm{AH}-1 \mathrm{~W}$ designation. Deliveries of $\mathrm{AH}-1 \mathrm{~W}$ Super Cobras totaled 179 new built helicopters plus 43 upgrades of AH-1Ts.

The $\mathrm{AH}-1 \mathrm{~T}+$ demonstrator and $\mathrm{AH}-1 \mathrm{~W}$ prototype were later tested with a new experimental composite four-blade main rotor system. The new system offered better performance, reduced noise and improved battle damage tolerance. Lacking a USMC contract, Bell developed this new design into the AH-1Z with its own funds. By 1996, the Marines were again not allowed to order the AH-64. Developing a marine version of the Apache would have been expensive and it was likely that the Marine Corps would be its only customer. They instead signed a contract for upgrading $180 \mathrm{AH}-1 \mathrm{Ws}$ into $\mathrm{AH}-1 \mathrm{Zs}$.

The AH-1Z Viper features several design changes. The AH-1Z's two redesigned wing stubs are longer with each adding a wing-tip station for a missile such as the AIM-9 Sidewinder. Each wing has two other stations for $70 \mathrm{~mm}$ (2.75 in) Hydra rocket pods, or AGM-114 Hellfire quad missile launcher. The Longbow radar can be mounted on a wingtip station.

During the closing months of the United States' involvement in the Vietnam War, the Marine Corps embarked the AH-1J SeaCobra assigned to HMA-369 (now HMLA-369) aboard the USS Denver (LPD-9), USS Cleveland (LPD-7) and later the USS Dubuque (LPD-8), for sea-based interdiction of the Ho Chi Minh Trail in North Vietnam in the vicinity of Hon La (Tiger) Island. These were termed Marine Hunter-Killer (MARHUK) Operations and lasted from June to December 1972.

Marine Cobras took part in the invasion of Grenada, during Operation Urgent Fury in 1983, flying closesupport and helicopter escort missions. Two Marine AH1Ts were shot down and three crew members killed. The Marines also deployed the AH-1 off the coast of Beirut, Lebanon in 1983, during that nation's civil war. The AH1s were armed with Sidewinder missiles and guns as an emergency air defense measure against the threat of light civil aircraft employed by suicide bombers.

USMC Cobras provided escort in the Persian Gulf in the late 1980s while the Iran-Iraq War was ongoing. The Cobras sank three Iranian patrol boats while losing one AH$1 \mathrm{~T}$ to Iranian anti-aircraft fire. USMC Cobras from the USS Saipan (LHA-2) flew "top cover" during an evacuation of American and other foreign nationals from Liberia in 1990.
During the Gulf War, 78 Marine Super Cobras deployed and flew a total of 1,273 sorties in Iraq with no combat losses. However, three AH-1s were lost to accidents during and after the combat operations. The AH$1 \mathrm{~W}$ units were credited with destroying 97 tanks, 104 armored personnel carriers and vehicles and two antiaircraft artillery sites during the 100-h ground campaign.

Marine Cobras provided support for the US humanitarian intervention in Somalia, during Operation Restore Hope in 1992-1993. They were also employed during the U.S. invasion of Haiti in 1994. USMC Cobras were used in U.S. military interventions in the former Yugoslavia in the 1990s and assisted in the rescue of USAF Captain Scott O'Grady, after his F-16 was shot down by a SAM in June 1995.

AH-1 Cobras continue to operate with the U.S. Marine Corps. USMC Cobras were also used in operations throughout the 1990s. USMC Cobras have also served in Operation Enduring Freedom in Afghanistan and in Operation Iraqi Freedom in the ongoing conflict in Iraq. While new replacement aircraft was considered as an alternative to major upgrades of the AH-1 fleet, Marine Corps studies showed that an upgrade was the most affordable, most supportable and most effective solution for the Marine Corps light attack helicopter mission.

In 1971, Iran purchased 202 improved AH-1J Cobras, with the name "AH-IJ International", from the United States. This improved Cobra, known as the AH-1J International, resulted from this contract featured an uprated $\mathrm{P}$ and WC T400-WV-402 engine and stronger drivetrain. Recoil damping gear was fitted to the $20 \mathrm{~mm}$ gun turret and the gunner was given a stabilized sight and even a stabilized chair. 62 of the International AH-1Js delivered to the Shah's forces were TOW-capable, while the rest were not.

They participated in the Iran-Iraq War. Iranian AH-1J SeaCobras engaged in air combat with Iraqi Mi-24s on several separate occasions during the war. The results of these engagements are disputed. One document cited that "Iranian AH-1Js engaged Iraqi MI-8 Hip and MI-24 Hind helicopters. Unclassified sources report that the Iranian AH-1 pilots achieved a 10:1 kill ratio over the Iraqi helicopter pilots during these engagements (1:5). Additionally, Iranian AH-1 and Iraqi fixed-wing aircraft engagements also occurred. Others claim that in the entire eight-year conflict, ten Iranian AH-1Js were lost in combat, compared to six Iraqi Mi-24s. The skirmishes are described as fairly evenly matched in another source. Iranian AH-1Js are still operating today and have undergone indigenous upgrade programs. In 1988, two Soviet MiG-23s shot down a pair of Iranian AH-1Js that had strayed into western Afghan airspace.

Turkey bought ten AH-1W Super Cobras in the early 1990s and supplemented this fleet with 32 ex-US Army AH-1 Cobras. The US Army Cobras included some TAH-1P trainers, while the rest were brought up to AH$1 \mathrm{~F}$ standard. AH-1Ws have been used in the war against the Kurdistan Workers' Party, or PKK. Turkey seeks to purchase nine additional AH-1Ws, but the US seems 
unwilling to sell them. However, Turkey is to obtain two AH-1Ws from the USMC inventory in 2011.

The Bell AH-1Z Viper (Fig. 10) is a twin-engine attack helicopter based on the AH-1W Super Cobra, that was developed for the United States Marine Corps. The AH-1Z features a four-blade, bearingless, composite main rotor system, uprated transmission and a new target sighting system. The $\mathrm{AH}-1 \mathrm{Z}$ is part of the $\mathrm{H}-1$ upgrade program. It is also called "Zulu Cobra" in reference to its variant letter.

The MH-6 Little Bird (also known as Killer Egg) and its attack variant, the AH-6 (Fig. 11), are single-engine light helicopters used for special operations aviation in the United States Army.

Originally based on a modified OH-6A, it was later based on the MD 500E, with a single five-bladed main rotor. The newest version, the MH-6M, is based on the MD 530F and has a single, six-bladed main rotor and four-bladed tail rotor.

The Boeing AH-64 Apache (Fig. 12) is a four-blade, twin-engine attack helicopter with a tailwheel-type landing gear arrangement and a tandem cockpit for a crew of two. The Apache was developed as Model 77 by Hughes Helicopters for the United States Army's Advanced Attack Helicopter program to replace the AH-1 Cobra. First flown on 30 September 1975, the AH-64 features a nose-mounted sensor suite for target acquisition and night vision systems. The Apache is armed with a $30 \mathrm{~mm}$ (1.2 in) M230 Chain Gun carried between the main landing gear, under the aircraft's forward fuselage. It has four hardpoints mounted on stub-wing pylons, typically carrying a mixture of AGM114 Hellfire and Hydra 70 rocket pods. The AH-64 also features double- and triple-redundant aircraft systems to improve survivability for the aircraft and crew in combat, as well as improved crash survivability for the pilots.

The U.S. Army selected the AH-64 over the Bell YAH-63 in 1976, awarding Hughes Helicopters a preproduction contract for two more aircraft. In 1982, the Army approved full production. McDonnell Douglas continued production and development after purchasing Hughes Helicopters from Summa Corporation in 1984. The first production AH-64D Apache Longbow, a greatly upgraded version of the original Apache, was delivered to the Army in March 1997. AH-64 production is continued by the Boeing Defense, Space and Security division; over one thousand AH-64s have been produced to date.

The U.S. Army is the primary operator of the AH-64, however, it has also become the primary attack helicopter of several nations it has been exported to, including Greece, Japan, Israel, the Netherlands and Singapore; as well as being produced under license in the United Kingdom as the Agusta Westland Apache. U.S. AH-64s have served in conflicts in Panama, Persian Gulf War, Kosovo War, Afghanistan and Iraq. Israel has made active use of the Apache in its military conflicts in Lebanon and Gaza Strip; while two coalition allies have deployed their AH-64s in Afghanistan and Iraq.

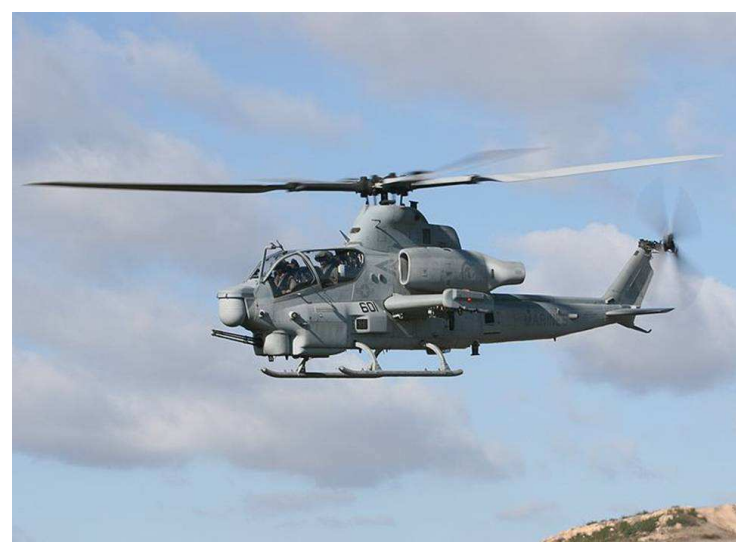

Fig. 10. The bell AH-1Z viper. Source: Petrescu and Petrescu (2011)

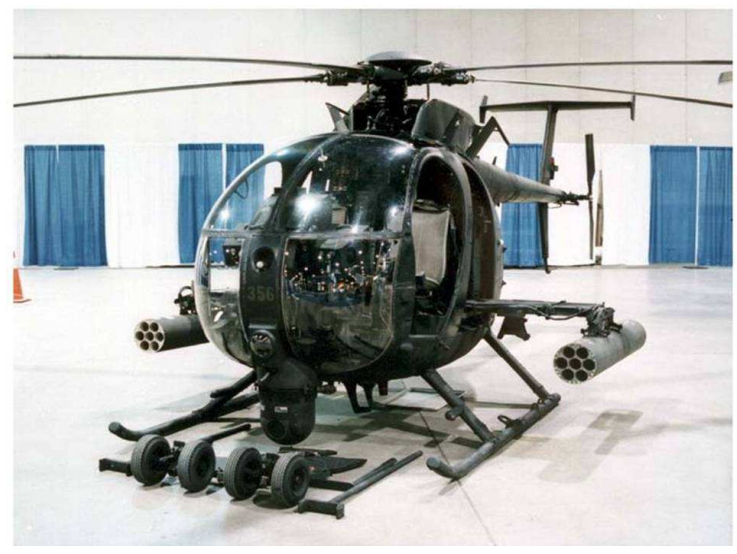

Fig. 11. The AH-6 little bird. Source: Petrescu and Petrescu (2011)

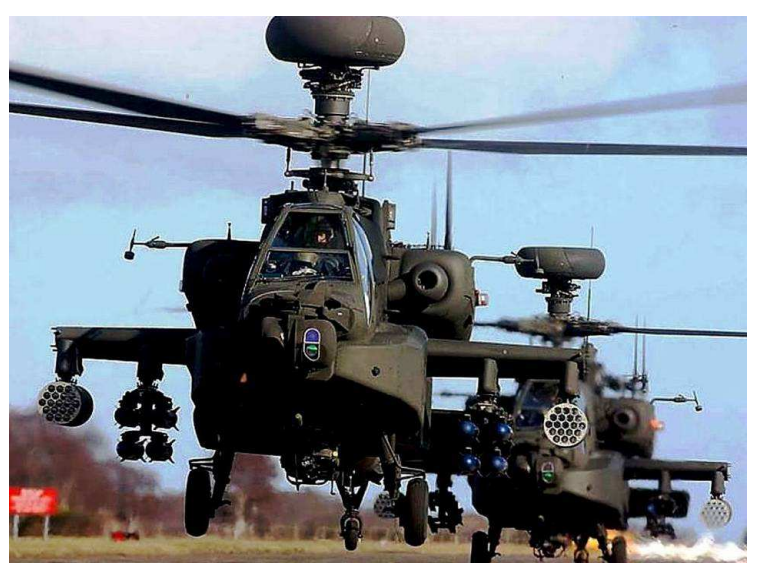

Fig. 12. The AH-64 apache. Source: Petrescu and Petrescu (2011)

Following the cancellation of the AH-56 Cheyenne in 1972, in favor of United States Air Force and Marine Corps projects like the A-10 Thunderbolt II and Harrier, the United States Army sought an aircraft to fill an anti-armor 
attack role that would still be under Army command; the 1948 Key West Agreement forbade the Army from owning fixed-wing aircraft. The Army wanted an aircraft better than the AH-1 Cobra in firepower, performance and range. It would have the maneuverability for terrain following napof-the-earth (NoE) flying. To this end, the US Army issued a Request for Proposals (RFP) for an Advanced Attack Helicopter (AAH) on 15 November 1972. As a sign of the importance of this project, in September 1973 the Army designated their five most important projects, the "Big Five" with AAH included.

Proposals were submitted by Bell, Boeing Vertol/Grumman team, Hughes, Lockheed and Sikorsky. In July 1973, the U.S. Department of Defense selected finalists Bell and Hughes Aircraft's Toolco Aircraft Division (later Hughes Helicopters). This began the phase 1 of the competition. Each company built prototype helicopters and went through a flight test program. Hughes' Model 77/YAH-64A prototype first flew on 30 September 1975, while Bell's Model 409/YAH-63A prototype first flew on 1 October. After evaluating test results, the Army selected Hughes' YAH-64A over Bell's YAH-63A in 1976. Reasons for selecting the YAH-64A included its more damage tolerant four-blade main rotor and the instability of the YAH-63's tricycle landing gear arrangement.

The AH-64A then entered phase 2 of the AAH program. This called for building three pre-production AH-64s and upgrading the two YAH-64A flight prototypes and the ground test unit up to the same standard. Weapons and sensor systems were integrated and tested during this time, including the new Hellfire missile.

In 1981, three pre-production AH-64As were handed over to the US Army for Operational Test II. The Army testing was successful, but afterward, it was decided to upgrade to the more powerful T700-GE-701 version of the engine, rated at 1,690 shp $(1,259 \mathrm{~kW})$. The AH-64 was named the Apache in late 1981, keeping with the Army's traditional use of American Indian tribal names for its helicopters and it was approved for full-scale production in 1982. In 1983, the first production helicopter was rolled out at Hughes Helicopter's facility in Mesa, Arizona. Hughes Helicopters was purchased by McDonnell Douglas for $\$ 470$ million in 1984 . The helicopter unit later became part of The Boeing Company with the merger of Boeing and McDonnell Douglas in August 1997. In 1986, the incremental or flyaway cost for the AH-64A was US\$7.03 million and the average unit cost was approximately US\$13.9 million based on total costs.

In the mid-1980s, McDonnell Douglas studied an improved "AH-64B" design with an updated cockpit, new fire control system and other upgrades. In 1988 funding was approved for a multi-stage upgrade program to improve sensor and weapon avionic systems and incorporate some digital systems. However, improved technology was becoming available. It was decided to cancel the upgrade program for more ambitious changes. This would lead to the more advanced AH-64D Apache
Longbow. Development of the AH-64D was approved by the Defense Acquisition Board in August 1990. The first AH-64D Apache Longbow prototype was flown on 15 April 1992 and testing of the prototypes ended in April 1995 after they had significantly outperformed the AH64A model. On 13 October 1995 full-scale production of the Apache Longbow was approved and a \$1.9 billion five-year contract was signed in August 1996 to upgrade and rebuild 232 existing AH-64 Apaches. The first production AH-64D flew on 17 March 1997 and was delivered on 31 March 1997. The cost of the AH-64D program totaled US\$11 billion through 2007.

The Apache has a four-blade main rotor and a fourblade tail rotor. The crew sits in tandem, with the pilot sitting behind and above the copilot/gunner. The crew compartment and fuel tanks are armored such that the aircraft will remain flyable even after sustaining hits from $23 \mathrm{~mm}$ (0.91 in) gunfire.

The AH-64 is powered by two General Electric T700 turboshaft engines with high-mounted exhausts on either side of the fuselage. Various models of engines have been used on the Apache, those in British service use engines from Rolls-Royce instead of General Electric. In 2004, General Electric Aviation began producing more powerful T700-GE-701D engines, rated at 2,000 shp $(1,500 \mathrm{~kW})$ for AH-64Ds.

One of the revolutionary features at the introduction of the Apache was its helmet mounted display, the Integrated Helmet and Display Sighting System (IHADSS); among other abilities the pilot or gunner can slave the helicopter's $30 \mathrm{~mm}$ automatic M 230 Chain Gun to his helmet, making the gun track head movements to point at where he looks. The M230E1 can be alternatively fixed to a locked forward firing position or controlled via the Target Acquisition and Designation System (TADS).

The AH-64 is designed to endure front-line environments and to operate during the day or night and in adverse weather using avionics, such as the Target Acquisition and Designation System, Pilot Night Vision System (TADS/PNVS), passive infrared countermeasures, GPS and the IHADSS. A newer system that is replacing TADS/PNVS is Arrowhead (MTADS); it is manufactured by Lockheed Martin, a contract was made on 17 February 2005 to begin equipping all models of American Apaches.

The AH-64 is adaptable to numerous different roles within its context as Close Combat Attack (CCA) and has a customizable weapons loadout for the role desired. In addition to the $30-\mathrm{mm}$ M230E1 Chain Gun, the Apache carries a range of external stores on its stub-wing pylons, typically a mixture of AGM-114 Hellfire antitank missiles and Hydra 70 general-purpose unguided 70 $\mathrm{mm}$ (2.76 in) rockets. The Stinger and AIM-9 Sidewinder air-to-air missiles and the AGM-122 Sidearm antiradiation missile were evaluated beginning in the late 1980s. The Stinger was initially selected over the AIM-9, but the US Army is considering the Starstreak air-to-air missile instead. The stub-wing pylons also have mounting 
points for use during ground helicopter maintenance; though in the case of emergency the mount points can be used for harnessing personnel to the wings during transport. External fuel tanks can also be carried by the pylons to increase range and mission time.

The U.S. Army formally accepted its first production AH-64A in January 1984 and training of the first pilots began later that year. The first operational Apache unit, 7th Battalion, $17^{\text {th }}$ Cavalry Brigade, began training on the AH-64A in April 1986 at Fort Hood, Texas. Two operational units with $68 \mathrm{AH}-64 \mathrm{~s}$ first deployed to Europe in September 1987 and took part in large military exercises there. The helicopter was first used in combat in 1989, during Operation Just Cause, the invasion of Panama. The AH-64 participated in over $240 \mathrm{~h}$ of combat attacking various targets, mostly at night.

During Operation Desert Storm on 17 January 1991, eight AH-64As guided by four MH-53 Pave Low IIIs, were used to destroy a portion of the Iraqi radar network. This was the first attack of Desert Storm and it allowed attack aircraft into Iraq without detection. The Apaches carried an asymmetric load of Hydra 70 flechette rockets, Hellfires and one auxiliary fuel tank each. During the 100-h ground war, a total of 277 AH-64s took part, destroying over 500 tanks, numerous armored personnel carriers and other Iraqi vehicles. Only one AH-64 was lost in the war. It was hit by an RPG at close range and crashed, but the crew survived.

The AH-64 played roles in the Balkans during separate conflicts in Bosnia and Kosovo in the 1990s. During these deployments, the Apache encountered problems such as deficiencies in training, night vision equipment, fuel tanks and survivability on 27 April 1999, an Apache crashed during training in Albania due to a failure with the tail rotor, causing the entire fleet in the Balkans to be grounded in December 2000. Major General Dick Cody, commanding officer of the $101^{\text {st }}$ Airborne at the time, wrote a strongly worded memo to the US Army Chief of Staff about the failures in training and equipment.

The AH-64 took part in the invasion of Iraq in 2003 during Operation Iraqi Freedom. In one engagement on 24 March 2003, 31 Apaches were damaged and one Apache was shot down and captured by Iraqi troops near Karbala. The intended attack against an armored brigade of the Iraqi Republican Guard's Medina Division was unsuccessful. The tank crews had set up a "flak trap" amongst terrain and employed their guns to good effect. Iraqi officials claimed a farmer with a Brno rifle shot down the Apache, however, the farmer denied involvement. The helicopter came down intact and both the pilot and co-pilot were captured. The AH-64D was destroyed via air strike the following day.

The U.S. Apaches have been serving in Operation Enduring Freedom in Afghanistan from 2001. American AH-64Ds are flying in Iraq and Afghanistan without the
Longbow Fire Control Radar as there are no armored threats to be dealt with. Most Apache helicopters that have taken heavy combat damage have been able to continue their missions and return safely. In 2006, an Apache helicopter was downed by a Soviet-made Strela 2 (SA-7) in Iraq. The Apache is typically able to avoid hits by such missiles; however, in this instance, it did not. As of 2009, 12 Apache helicopters were shot down by enemy fire during the Iraq War.

According to Boeing, the U.S. Army Apache fleet has accumulated more than 2 million flight hours since the first prototype aircraft flew in 1975.

The UK operates a modified version of the Apache Longbow initially called the Westland WAH-64 Apache and is designated Apache AH1 by the British Army. Westland built 67 WAH-64 Apaches under license from Boeing, following a competition between the Eurocopter Tiger and the Apache for the British Army's new Attack Helicopter in 1995. Important deviations made by Agusta Westland from the US variants of the Apache include replacing the engines with more powerful RollsRoyce units and the addition of a folding blade assembly for naval use; allowing British Apaches to operate from Royal Navy warships and auxiliaries.

The Eurocopter AS332 Super Puma (Fig. 13) is a four-bladed, twin-engine, medium-size utility helicopter marketed for both civil and military use. Originally designed and built by Aérospatiale, it is an enlarged and re-engined version of the original Aérospatiale Puma. The Super Puma first flew on 13 September 1978.

In 1974, Aérospatiale commenced development of a new medium transport helicopter based on its SA 330 Puma, announcing the project at the 1975 Paris Air Show. While the new design was of similar layout to the AS 330, it was powered by two of the new and more powerful Turbomeca Makila turboshaft engines powering a four-bladed composite main rotor and was designed to be withstand damage better, with a more robust fuselage structure, a new crashworthy undercarriage and the ability to withstand battle damage to the rotor blades and other key mechanical systems. It was fitted with a ventral fin under the tail a more streamlined nose compared with the SA 330, while from the start was planned to be available in two fuselage lengths, with a short fuselage version offering similar capacity to the SA 330, which gives better performance in "hot and high" conditions and a stretched version allowing more passengers to be carried when weight is less critical.

A pre-production prototype, the SA 331, modified from an SA 330 airframe with Makila engines and a new gearbox, flew on 5 September 1977. The first prototype of the full Super Puma made its maiden flight on 13 September 1978, being followed by a further five prototypes. 


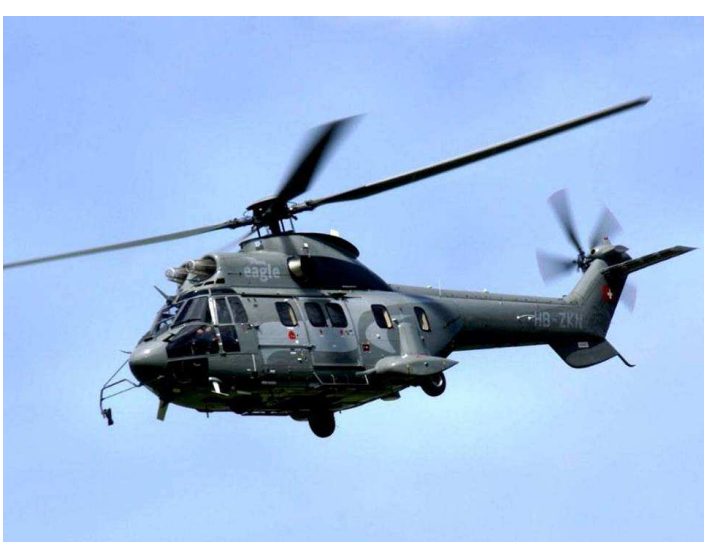

Fig. 13. The Eurocopter AS332 Super Puma. Source: Petrescu and Petrescu (2011)

The type has proved immensely successful, chosen by 37 military forces around the world and some 1,000 civil operators. The Super Puma has proved especially wellsuited to the North Sea oil industry, where it is used to ferry personnel and equipment to and from oil platforms. In the civilian configuration, it can seat approximately 18 passengers and two crew, though since the early 2000 s most oil companies have banned the use of the middle-rear seat reducing effective capacity to $17+2$. This down-rating is due to difficulties encountered in evacuating through the rear-most windows in crashes at sea.

A wide variety of specialized military variants is in use, including dedicated Search and Rescue (SAR) and AntiSubmarine Warfare (ASW) versions. Since 1990, military Super Pumas have been marketed as the AS532 Cougar.

The Boeing CH-47 Chinook (Fig. 14) is a twinengine, tandem rotor heavy-lift helicopter. Its top speed of 170 knots $(196 \mathrm{mph}, 315 \mathrm{~km} / \mathrm{h})$ was faster than contemporary utility and attack helicopters of the 1960s.

It is one of the few aircraft of that era, such as the C130 Hercules and the UH-1 Iroquois, that is still in production and front line service with over 1,179 built to date. Its primary roles include troop movement, artillery emplacement and battlefield resupply. It has a wide loading ramp at the rear of the fuselage and three external-cargo hooks.

The Chinook was designed and initially produced by Boeing Vertol in the early 1960s. The helicopter is now produced by Boeing Rotorcraft Systems. Chinooks have been sold to 16 nations with the US Army and the Royal Air Force (see Boeing Chinook (UK variants)) being the largest users. The $\mathrm{CH}-47$ is among the heaviest lifting Western helicopters.

In late 1956, the Department of the Army announced plans to replace the $\mathrm{CH}-37$ Mojave, which was powered by piston engines, with a new, turbine-powered helicopter. Turbine engines were also a key design feature of the smaller UH-1 "Huey" utility helicopter. Following a design competition, in September 1958, a joint Army-Air Force source selection board recommended that the Army procure the Vertol medium transport helicopter. However, funding for full-scale development was not then available and the Army vacillated on its design requirements. Some in the Army aviation corps thought that the new helicopter should be a light tactical transport aimed at taking over the missions of the old piston-engined $\mathrm{H}-21$ and H-34 helicopters and consequently capable of carrying about fifteen troops (one squad). Another faction in the Army aviation corps thought that the new helicopter should be much larger to be able to airlift a large artillery piece and have enough internal space to carry the new MGM-31 "Pershing" Missile System.

Vertol began work on a new tandem-rotor helicopter designated Vertol Model 107 or V-107 in 1957. In June 1958, the US Army awarded a contract to Vertol for the aircraft under the YHC-1A designation. The YHC-1A had a capacity for 20 troops. Three were tested by the Army to derive engineering and operational data. However, the YHC-1A was considered by most of the Army users to be too heavy for the assault role and too light for the transport role. The decision was made to procure a heavier transport helicopter and at the same time upgrade the UH-1 "Huey" as a tactical troop transport. The YHC-1A would be improved and adopted by the Marines as the $\mathrm{CH}-46$ Sea Knight in 1962. The Army then ordered the larger Model 114 under the designation HC-1B. The pre-production Boeing Vertol YCH-1B made its initial hovering flight on 21 September 1961. In 1962 the HC-1B was redesignated the CH-47A under the 1962 United States Tri-Service aircraft designation system.

The name "Chinook" alludes to the Chinook people of the Pacific Northwest. The $\mathrm{CH}-47$ is powered by two turboshaft engines, mounted on each side of the helicopter's rear end and connected to the rotors by driveshafts. Initial models were fitted with engines of 2,200 horsepower. The counter-rotating rotors eliminate the need for an anti-torque vertical rotor, allowing all power to be used for lift and thrust. The ability to adjust lift in either rotor makes it less sensitive to changes in the center of gravity, important for the cargo lifting role. If one engine fails, the other can drive both rotors. The "sizing" of the Chinook was directly related to the growth of the Huey and the Army's tacticians' insistence that initial air assaults be built around the squad. The Army pushed for both the Huey and the Chinook and this focus was responsible for the acceleration of its air mobility effort.

Improved and more powerful versions of the $\mathrm{CH}-47$ have been developed since the helicopter entered service. The US Army's first major design leap was the nowcommon CH-47D, which entered service in 1982. Improvements from the $\mathrm{CH}-47 \mathrm{C}$ included upgraded engines, composite rotor blades, a redesigned cockpit to reduce pilot workload, improved and redundant electrical systems, an advanced flight control system and improved avionics. The latest mainstream generation is the $\mathrm{CH}$ $47 \mathrm{~F}$, which features several major upgrades to reduce maintenance, digitized flight controls and is powered by two 4,733-horsepower Honeywell engines. 


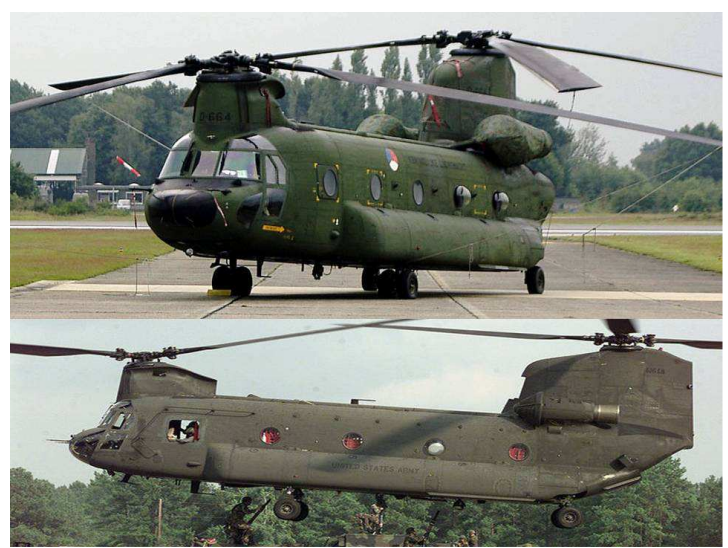

Fig. 14. The boeing CH-47 Chinook. Source: Petrescu and Petrescu, 2011

A commercial model of the Chinook, the BoeingVertol Model 234, is used worldwide for logging, construction, fighting forest fires and supporting petroleum extraction operations. On 15 December 2006, the Columbia Helicopters company of the Salem, Oregon, metropolitan area, purchased the Type Certificate of the Model 234 from Boeing. The Chinook has also been licensed to be built by companies outside of the United States, such as Elicotteri Meridionali (now Agusta Westland) in Italy, Kawasaki in Japan and a company in the United Kingdom.

The Army finally settled on the larger Chinook as its standard medium transport helicopter and as of February 1966, 161 aircraft had been delivered to the Army. The 1st Cavalry Division had brought their organic Chinook battalion with them when they arrived in 1965 and a separate aviation medium helicopter company, the 147th, had arrived in Vietnam on 29 November 1965. This latter company was initially placed in direct support of the 1st Infantry Division.

The most spectacular mission in Vietnam for the Chinook was the placing of artillery batteries in perilous mountain positions inaccessible by any other means and then keeping them resupplied with large quantities of ammunition. The 1st Cavalry Division found that its Chinooks were limited to 7,000 pounds payload when operating in the mountains, but could carry an additional 1,000 pounds when operating near the coast. The early Chinook design was limited by its rotor system which did not permit full use of the installed power and users were anxious for an improved version which would upgrade this system.

As with any new piece of equipment, the Chinook presented a major problem of "customer education". Commanders and crew chiefs had to be constantly alert that eager soldiers did not overload the temptingly large cargo compartment. It would be some time before troops would be experts at using sling loads. The Chinook soon proved to be such an invaluable aircraft for artillery movement and heavy logistics that it was seldom used as an assault troop carrier. Some of the Chinook fleets were used for casualty evacuation, due to the very heavy demand for the helicopters they were usually overburdened with wounded. Perhaps the most cost-effective use of the Chinook was the recovery of other downed aircraft.

The Chinooks were generally armed with a single $7.62 \mathrm{~mm} \mathrm{M} 60$ machine gun on a pintle mount on either side of the machine for self-defense, with stops fitted to keep the gunners from firing into the rotor blades. Dust filters were also added to improve engine reliability. At its peak employment in Vietnam, there were 22 Chinook units in operation.

Of the nearly 750 Chinooks in the US and Republic of Vietnam fleets, about 200 were lost in combat or wartime operational accidents. US Army supplied Chinooks to the Australian Task Force as required.

During the 1970s, the United States and Iran had a strong relationship, in which the Iranian armed forces began to use many American military aircraft, most notably the F-14 Tomcat, as part of a modernisation program. After an agreement signed between Boeing and Elicotteri Meridionali, the Imperial Iranian Air Force purchased 20 Elicotteri Meridionali-built $\mathrm{CH}-47 \mathrm{Cs}$ in 1971. The Imperial Iranian Army Aviation purchased 70 $\mathrm{CH}-47 \mathrm{Cs}$ from Elicotteri Meridionali during the period of 1972-1976. In late 1978, Iran placed an order for an additional 50 helicopters with Elicotteri Meridionali, but that order was canceled immediately after the revolution. Despite the arms embargo on place upon Iran, they have managed to keep their fleet operational.

In the 1978 Iranian Chinook shoot down, four Iranian $\mathrm{CH}-47 \mathrm{C}$ Chinooks penetrated $15-20 \mathrm{~km}$ into Soviet airspace in the Turkmenistan Military District. They were intercepted by a MiG-23M which shot down one Chinook, killing eight crew members and forced the second one to land. Chinooks were used in efforts by the Imperial Iranian loyalist forces to resist the 1979 Iranian revolution. During the war with Iraq, Iran made heavy use of its USbought equipment and lost at least 8 Chinooks during the 1980-1988 period; most notably during a clash on 15 July 1983, where an Iraqi Mirage F-1 destroyed three Iranian $\mathrm{CH}-47 \mathrm{~s}$ transporting troops to the front line.

The Chinook was used both by Argentina and the United Kingdom during the Falklands War in 1982. The Argentine Air Force and the Argentine Army deployed four $\mathrm{CH}-47 \mathrm{C}$ (two each) which were widely used in general transport duties. Of the Army's airframes, one was destroyed on the ground by a Harrier while the other was captured (and reused after the war) by the British. Both Air Force helicopters returned to Argentina and remained in service until 2002.

Approximately $163 \mathrm{CH}-47 \mathrm{Ds}$ served in Kuwait and Iraq during Operations Desert Shield and Desert Storm in 1990-91. 
The CH-47D has been seen wide use in Operation Enduring Freedom in Afghanistan and Operation Iraqi Freedom in Iraq. The Chinook is being used in air assault missions, inserting troops into fire bases and later bringing food, water and ammunition. It is also the casualty evacuation (casevac) aircraft of choice in the British Army. In today's usage, it is typically escorted by attack helicopters such as the AH-64 Apache for protection. Its tandem rotor design and lift capacity have been found to be particularly useful in the mountainous terrain of Afghanistan where high altitudes and temperatures limit the use of the UH-60 Black Hawk. The CH-47F is being fielded by more units such as the 101st Combat Aviation Brigade and 4th Combat Aviation Brigade in the U.S. Army as it continues to operate in Afghanistan.

The Chinooks of several nations have participated in the Afghanistan War, including aircraft from Britain, Italy, the Netherlands, Spain, Canada and Australia. Despite the age of the Chinook, it is still in heavy demand, in part due to its proven versatility and ability to operate in demanding environments such as Afghanistan.

Three CH-47 Chinooks were used to cool Reactors 3 and 4 of the Fukushima Nuclear power plant with sea water after the 9.0 earthquake in 2011. To protect the crew from the heightened radiation levels, lead plates were attached to the floor.

The Sikorsky CH-53E Super Stallion (Fig. 15) is the largest and heaviest helicopter in the United States military. It was developed from the CH-53 Sea Stallion, mainly by adding a third engine. Sailors commonly refer to the Super Stallion as the "Hurricane Maker" because of the downwash the helicopter generates. It was built by Sikorsky Aircraft for the United States Marine Corps. The less common MH53E Sea Dragon fills the United States Navy's need for long range mine sweeping or Airborne Mine Countermeasures (AMCM) missions and perform heavy-lift duties for the Navy. The CH-53E/MH-53E are designated "S-80" by Sikorsky. Currently under development is the CH-53K, which will be equipped with new engines, new composite rotor blades and a wider cabin.

The Eurocopter Tiger (company designation EC 665), (Fig. 16), is an attack helicopter manufactured by Eurocopter. In Germany it is known as the Tiger; in France and Spain, it is called the Tigre.

The Sikorsky $\mathrm{X}_{2}$ (Fig. 17) is an experimental compound helicopter with coaxial rotors under development by the American aircraft manufacturer Sikorsky Aircraft.

Sikorsky has incorporated decades of company research and development into $\mathrm{X}_{2}$ Technology helicopters. The S69/XH-59A Advancing Blade Concept Demonstrator showed high speed was possible with a coaxial helicopter and auxiliary propulsion; the Cypher UAV expanded company knowledge of the unique aspects of flight control laws in a fly by wire aircraft with coaxial rotors; and the RAH-66 Comanche, which developed expertise in composite rotors and advanced transmission design.

On 4 May 2009, Sikorsky unveiled a mock-up of a Light Tactical Helicopter derivative of the $\mathrm{X}_{2}$.

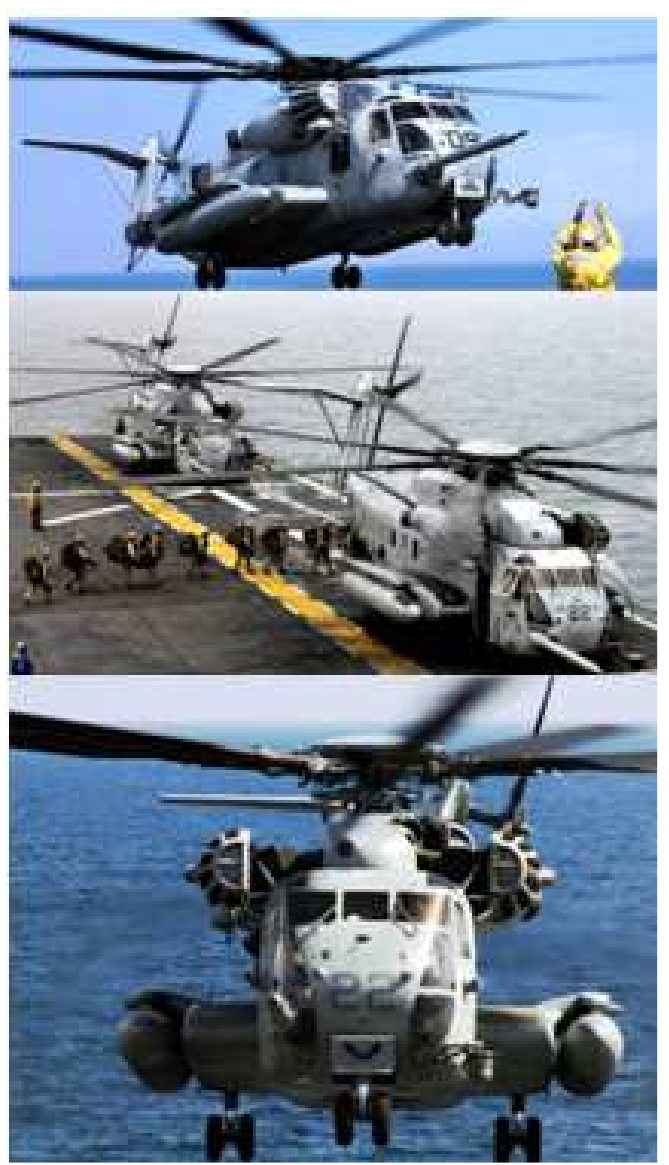

Fig. 15. The Sikorsky CH-53E super stallion. Source: Petrescu and Petrescu (2011)

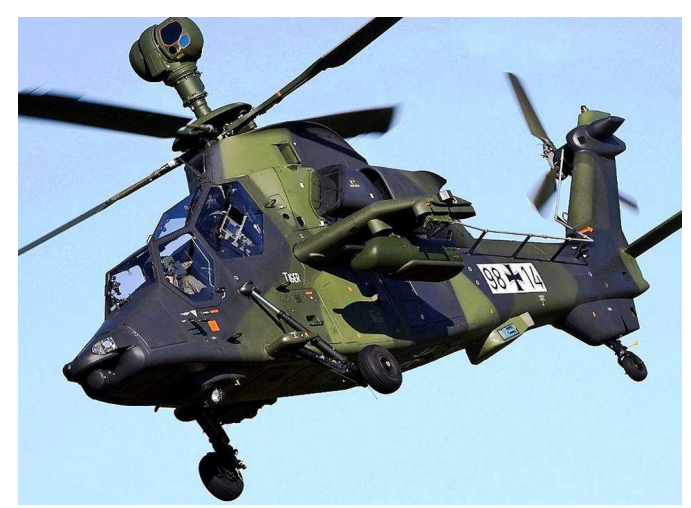

Fig. 16. The eurocopter tiger EC 665. Source: Petrescu and Petrescu (2011)

The $\mathrm{X}_{2}$ first flew on 27 August 2008 from Schweizer Aircraft's (a division of Sikorsky Aircraft Corporation) facility at Horseheads, New York. The flight lasted $30 \mathrm{~min}$. This began a 4-phase flight test program, to culminate with reaching a planned 250-knot top speed. The $\mathrm{X}_{2}$ completed flights with its pusher propeller fully engaged in July 2009. Sikorsky completed Phase 3 of the testing with the $\mathrm{X}_{2}$ hitting 181 knots in the test flight in late May 2010. 


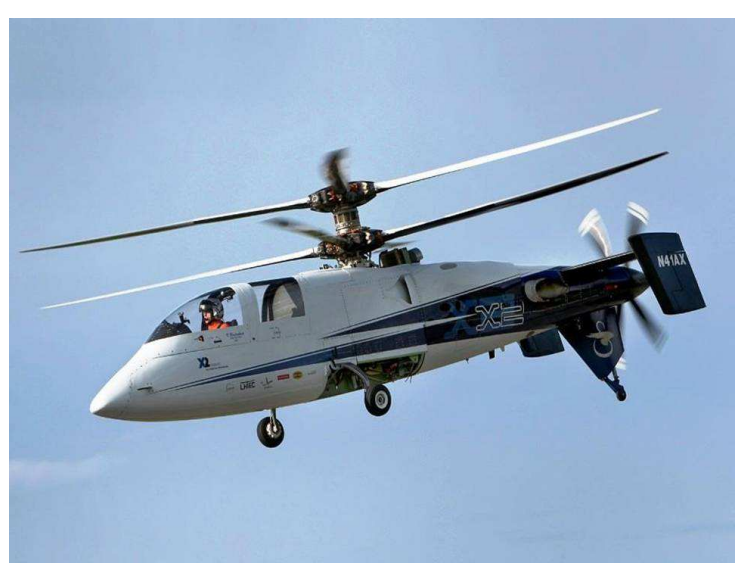

Fig. 17. The Sikorsky $\mathrm{X}_{2}$. Source: Petrescu and Petrescu (2011)

On 26 July 2010, Sikorsky announced that the $\mathrm{X}_{2}$ exceeded 225 knots $(259 \mathrm{mph} ; 417 \mathrm{~km} / \mathrm{h})$ during flight testing in West Palm Beach Florida, unofficially surpassing the current FAI Rotorcraft world speed record of 216 knots (249 $\mathrm{mph}$ ) set by a modified Westland Lynx in 1986. The $\mathrm{X}_{2}$ flight was purposefully made 37 years to the date of the S-69's first flight.

On 15 September 2010, test pilot Kevin Bredenbeck achieved Sikorsky's design goal for the $\mathrm{X}_{2}$ when he flew it at a speed of $250 \mathrm{knots}(290 \mathrm{mph} ; 460 \mathrm{~km} / \mathrm{h})$ in level flight, an unofficial speed record for a helicopter. The demonstrator also reached a speed of 260 knots (300 $\mathrm{mph} ; 480 \mathrm{~km} / \mathrm{h}$ ) in a shallow $2^{\circ}$ to $3^{\circ}$ dive.

\section{Results}

A helicopter is a type of rotorcraft in which lift and thrust are supplied by one or more engine-driven rotors. In contrast with fixed-wing aircraft, this allows the helicopter to take off and land vertically, to hover and to fly forwards, backward and laterally. These attributes allow helicopters to be used in congested or isolated areas where fixed-wing aircraft would not be able to take off or land. The capability to efficiently hover for extended periods of time allows a helicopter to accomplish tasks that fixed-wing aircraft and other forms of vertical takeoff and landing aircraft cannot perform.

The word 'helicopter' is adapted from the French hélicoptère, coined by Gustave de Ponton d'Amecourt in 1861, which originates from the Greek helix/helik = "twisted, curved" and pteron = "wing".

Helicopters were developed and built during the first half-century of flight, with the Focke-Wulf Fw 61 being the first operational helicopter in 1936. Some helicopters reached limited production, but it was not until 1942 that a helicopter designed by Igor Sikorsky reached full-scale production, with 131 aircraft built. Though most earlier designs used more than one main rotor, it was the single main rotor with antitorque tail rotor configuration of this design that would come to be recognized worldwide as the helicopter.
The earliest references for vertical flight have come from China. Since around $400 \mathrm{BC}$, Chinese children have played with bamboo flying toys and the 4th-century AD Daoist book Baopuzi ("Master who Embraces Simplicity") reportedly describes some of the ideas inherent to rotary wing aircraft.

Someone asked the master about the principles of mounting to dangerous heights and traveling into the vast inane. The Master said, "Some have made flying cars with wood from the inner part of the jujube tree, using ox-leather fastened to returning blades so as to set the machine in motion."

It was not until the early 1480 s when Leonardo da Vinci created a design for a machine that could be described as an "aerial screw" (Fig. 1), that any recorded advancement was made towards vertical flight. His notes suggested that he built small flying models, but there were no indications for any provision to stop the rotor from making the whole craft rotate. As scientific knowledge increased and became more accepted, men continued to pursue the idea of vertical flight. Many of these later models and machines would more closely resemble the ancient bamboo flying top with spinning wings, rather than Da Vinci's screw.

In July 1754, Mikhail Lomonosov demonstrated a small tandem rotor to the Russian Academy of Sciences. It was powered by a spring and suggested as a method to lift meteorological instruments. In 1783, Christian de Launoy and his mechanic, Bienvenu, made a model with a pair of counter-rotating rotors, using turkey flight feathers as rotor blades and in 1784, demonstrated it to the French Academy of Sciences. Sir George Cayley, influenced by a childhood fascination with the Chinese flying top, grew up to develop a model of feathers, similar to Launoy and Bienvenu but powered by rubber bands. By the end of the century, he had progressed to using sheets of tin for rotor blades and springs for power. His writings on his experiments and models would become influential on future aviation pioneers. Alphonse Pénaud would later develop coaxial rotor model helicopter toys in 1870 , also powered by rubber bands. One of these toys, given as a gift by their father, would inspire the Wright brothers to pursue the dream of flight.

\section{Discussion}

Hovering is the most challenging part of flying a helicopter. This is because a helicopter generates its own gusty air while in a hover, which acts against the fuselage and flight control surfaces. The end result is constant control inputs and corrections by the pilot to keep the helicopter where it is required to be. Despite the complexity of the task, the control inputs in a hover are simple. The cyclic is used to eliminate drift in the horizontal plane, that is to control forward and back, right and left. The collective is used to maintain altitude. The pedals are used to control nose direction or heading. 
It is the interaction of these controls that makes hovering so difficult, since an adjustment in any one control requires an adjustment of the other two, creating a cycle of constant correction.

\section{Transition from Hover to Forward Flights}

As a helicopter moves from hover to forward flight it enters a state called Translational lift which provides extra lift without increasing power. This state, most typically, occurs when the airspeed reaches approximately 16-24 knots and may be necessary for a helicopter to obtain flight.

\section{Forward Flight}

In forwarded flight, a helicopter's flight controls behave more like that in a fixed-wing aircraft. Displacing the cyclic forward will cause the nose to pitch down, with a resultant increase in airspeed and loss of altitude. Aft cyclic will cause the nose to pitch up, slowing the helicopter and causing it to climb. Increasing collective (power) while maintaining a constant airspeed will induce a climb while decreasing collective will cause a descent. Coordinating these two inputs, down collective plus aft cyclic or up collective plus forward cyclic, will result in airspeed changes while maintaining a constant altitude. The pedals serve the same function in both a helicopter and a fixed-wing aircraft, to maintain balanced flight. This is done by applying a pedal input in whichever direction is necessary to center the ball in the turn and bank indicator.

The main limitation of the helicopter is its low speed. There are several reasons a helicopter cannot fly as fast as a fixed-wing aircraft. When the helicopter is hovering, the outer tips of the rotor travel at a speed determined by the length of the blade and the RPM. In a moving helicopter, however, the speed of the blades relative to the air depends on the speed of the helicopter as well as on their rotational velocity.

The airspeed of the advancing rotor blade is much higher than that of the helicopter itself. It is possible for this blade to exceed the speed of sound and thus produce vastly increased drag and vibration. See Wave drag.

Because the advancing blade has higher airspeed than the retreating blade and generates a dissymmetry of lift, rotor blades are designed to "flap" -lift and twist in such a way that the advancing blade flaps up and develops a smaller angle of attack. Conversely, the retreating blade flaps down develops a higher angle of attack and generates more lift. At high speeds, the force on the rotors is such that they "flap" excessively and the retreating blade can reach too high an angle and stall. For this reason, the maximum safe forward airspeed of a helicopter is given a design rating called VNE, Velocity, Never Exceed.

In addition, it is possible for the helicopter to fly at an airspeed where an excessive amount of the retreating blade stalls which results in high vibration, pitch-up and roll into the retreating blade.
During the closing years of the $20^{\text {th }}$ century designers began working on helicopter noise reduction. Urban communities have often expressed great dislike of noisy aircraft and police and passenger helicopters can be unpopular.

The redesigns followed the closure of some city heliports and government action to constrain flight paths in national parks and other places of natural beauty.

Helicopters also vibrate; an unadjusted helicopter can easily vibrate so much that it will shake itself apart. To reduce vibration, all helicopters have rotor adjustments for height and weight. Blade height is adjusted by changing the pitch of the blade.

Weight is adjusted by adding or removing weights from the rotor head and/or at the blade end caps. Most also have vibration dampers for height and pitch. Some also use mechanical feedback systems to sense and counter vibration.

Usually, the feedback system uses a mass as a "stable reference" and a linkage from the mass operates a flap to adjust the rotor's angle of attack to counter the vibration. Adjustment is difficult in part because measurement of the vibration is hard, usually requiring sophisticated accelerometers mounted throughout the airframe and gearboxes.

The most common blade vibration adjustment measurement system is to use a stroboscopic flash lamp and observe painted markings or colored reflectors on the underside of the rotor blades. The traditional lowtech system is to mount colored chalk on the rotor tips and see how they mark a linen sheet. Gearbox vibration most often requires a gearbox overhaul or replacement. Gearbox or drive train vibrations can be extremely harmful to a pilot. The most severe being a pain, numbness, loss of tactile discrimination and dexterity.

\section{Canada Receives First CH-148 Maritime Helicopter}

The first interim maritime helicopter, the $\mathrm{CH}-148$ Cyclone, arrived at 12 Wing Shearwater, Nova Scotia, last week to support training of Canadian Forces (CF) aircrew and technicians for the Maritime Helicopter Project (Fig. 7).

"The arrival of this helicopter in Shearwater demonstrates progress with this project and brings us one step closer towards the delivery of a Maritime Helicopter capability that provides the Canadian Forces with a modern, flexible helicopter to assist in the defence of Canada and Canadian interests well into the future," said the Honourable Peter MacKay, Minister of National Defence.

\section{Conclusion}

A helicopter is a type of rotorcraft in which lift and thrust are supplied by one or more engine-driven rotors. In contrast with fixed-wing aircraft, this allows the helicopter to take off and land vertically, to hover and to fly forwards, backward and laterally. These attributes allow helicopters to be used in congested or isolated areas where fixed-wing aircraft would not be able to take off or land. 
The capability to efficiently hover for extended periods of time allows a helicopter to accomplish tasks that fixed-wing aircraft and other forms of vertical takeoff and landing aircraft cannot perform.

The word 'helicopter' is adapted from the French hélicoptère, coined by Gustave de Ponton d'Amecourt in 1861, which originates from the Greek helix/helik = "twisted, curved" and pteron = "wing". Helicopters were developed and built during the first half-century of flight, with the Focke-Wulf Fw 61 being the first operational helicopter in 1936. Some helicopters reached limited production, but it was not until 1942 that a helicopter designed by Igor Sikorsky reached full-scale production, with 131 aircraft built. Though most earlier designs used more than one main rotor, it was the single main rotor with antitorque tail rotor configuration of this design that would come to be recognized worldwide as the helicopter.

The earliest references for vertical flight have come from China. Since around $400 \mathrm{BC}$, Chinese children have played with bamboo flying toys and the 4th-century AD Daoist book Baopuzi ("Master who Embraces Simplicity") reportedly describes some of the ideas inherent to rotary wing aircraft: Someone asked the master about the principles of mounting to dangerous heights and traveling into the vast inane.

The Master said, "Some have made flying cars with wood from the inner part of the jujube tree, using oxleather fastened to returning blades so as to set the machine in motion."

It was not until the early 1480s when Leonardo da Vinci created a design for a machine that could be described as an "aerial screw" (Fig. 1-2), that any recorded advancement was made towards vertical flight. His notes suggested that he built small flying models, but there were no indications for any provision to stop the rotor from making the whole craft rotate. As scientific knowledge increased and became more accepted, men continued to pursue the idea of vertical flight. Many of these later models and machines would more closely resemble the ancient bamboo flying top with spinning wings, rather than Da Vinci's screw.

\section{Acknowledgement}

We acknowledge and thank Mr Taher M. Abu-Lebdeh, Associate Prof at North Carolina A and T State Univesity, United States and Mr Muftah H. El-Naas PhD MCIC FICCE QAFCO Chair Professor in Chemical Process Engineering Gas Processing Center College of Engineering Qatar University and Ms Shweta Agarwala, Senior Research Scientist at Singapore Center for 3D Printing Nanyang Technological University Singapore for their suggestions and comments. The Authors acknowledge Liquid Metals Technologies Inc, Ca USAthat kindly supply the samples for the characterization and Dr Francesco Tatti (FEI Company
Application Specialist SEM-SDB) for its contribut in the preparation of this paper experiments and analyses. The authors would like to appreciate the facilities and assistance provided by the Advanced Technology Dental Research Laboratory, Faculty of dentistry, King Abdul Aziz University. The authors would also appreciate the research technicians, Basim Al Turki and Fahad Al Othaibi for their cooperation (Aversa et al., 2016a; 2016b; 2016c; 2016d; 2016e; 2016f; 2016g; 2016h; 2016i; 2016j; 2016k; 2016l; 2016m; 2016n; 2016o, 2017a; 2017b; 2017c; 2017d; 2017e; Mirsayar et al., 2017).

\section{Author's Contributions}

All the authors contributed equally to prepare, develop and carry out this manuscript.

\section{Ethics}

This article is original and contains unpublished material. The corresponding author confirms that all of the other authors have read and approved the manuscript and no ethical issues involved.

\section{References}

Aversa, R., R.V.V. Petrescu, A. Apicella and F.I.T. Petrescu, 2017a. Nano-diamond hybrid materials for structural biomedical application. Am. J. Biochem. Biotechnol.

Aversa, R., R.V. Petrescu, B. Akash, R.B. Bucinell and J.M. Corchado et al., 2017b. Kinematics and forces to a new model forging manipulator. Am. J. Applied Sci., 14: 60-80.

Aversa, R., R.V. Petrescu, A. Apicella, I.T.F. Petrescu and J.K. Calautit et al., 2017c. Something about the $\mathrm{V}$ engines design. Am. J. Applied Sci., 14: 34-52.

Aversa, R., D. Parcesepe, R.V.V. Petrescu, F. Berto and G. Chen et al., 2017d. Process ability of bulk metallic glasses. Am. J. Applied Sci., 14: 294-301.

Aversa, R., R.V.V. Petrescu, B. Akash, R.B. Bucinell and J.M. Corchado et al., 2017e. Something about the balancing of thermal motors. Am. J. Eng. Applied Sci., 10: 200.217. DOI: 10.3844/ajeassp.2017.200.217

Aversa, R., F.I.T. Petrescu, R.V. Petrescu and A. Apicella, 2016a. Biomimetic FEA bone modeling for customized hybrid biological prostheses development. Am. J. Applied Sci., 13: 1060-1067. DOI: 10.3844/ajassp.2016.1060.1067

Aversa, R., D. Parcesepe, R.V. Petrescu, G. Chen and F.I.T. Petrescu et al., 2016b. Glassy amorphous metal injection molded induced morphological defects. Am. J. Applied Sci., 13: 1476-1482.

Aversa, R., R.V. Petrescu, F.I.T. Petrescu and A. Apicella, 2016c. Smart-factory: Optimization and process control of composite centrifuged pipes. Am. J. Applied Sci., 13: 1330-1341. 
Aversa, R., F. Tamburrino, R.V. Petrescu, F.I.T. Petrescu and M. Artur et al., 2016d. Biomechanically inspired shape memory effect machines driven by muscle like acting NiTi alloys. Am. J. Applied Sci., 13: 1264-1271.

Aversa, R., E.M. Buzea, R.V. Petrescu, A. Apicella and M. Neacsa et al., 2016e. Present a mechatronic system having able to determine the concentration of carotenoids. Am. J. Eng. Applied Sci., 9: 1106-1111.

Aversa, R., R.V. Petrescu, R. Sorrentino, F.I.T. Petrescu and A. Apicella, 2016f. Hybrid ceramo-polymeric nanocomposite for biomimetic scaffolds design and preparation. Am. J. Eng. Applied Sci., 9: 1096-1105.

Aversa, R., V. Perrotta, R.V. Petrescu, C. Misiano and F.I.T. Petrescu et al., 2016g. From structural colors to super-hydrophobicity and achromatic transparent protective coatings: Ion plating plasma assisted $\mathrm{TiO}_{2}$ and $\mathrm{SiO}_{2}$ Nano-film deposition. Am. J. Eng. Applied Sci., 9: 1037-1045.

Aversa, R., R.V. Petrescu, F.I.T. Petrescu and A. Apicella, 2016h Biomimetic and Evolutionary Design Driven Innovation in Sustainable Products Development, Am. J. Eng. Applied Sci., 9: 1027-1036.

Aversa, R., R.V. Petrescu, A. Apicella and F.I.T. Petrescu, 2016i. Mitochondria are naturally micro robots-a review. Am. J. Eng. Applied Sci., 9: 991-1002.

Aversa, R., R.V. Petrescu, A. Apicella and F.I.T. Petrescu, 2016j. We are addicted to vitamins $\mathrm{C}$ and E-A review. Am. J. Eng. Applied Sci., 9: 1003-1018.

Aversa, R., R.V. Petrescu, A. Apicella and F.I.T. Petrescu, 2016k. Physiologic human fluids and swelling behavior of hydrophilic biocompatible hybrid ceramo-polymeric materials. Am. J. Eng. Applied Sci., 9: 962-972.
Aversa, R., R.V. Petrescu, A. Apicella and F.I.T. Petrescu, 20161. One can slow down the aging through antioxidants. Am. J. Eng. Applied Sci., 9: 1112-1126.

Aversa, R., R.V. Petrescu, A. Apicella and F.I.T. Petrescu, $2016 \mathrm{~m}$. About homeopathy or «Similia similibus curentur». Am. J. Eng. Applied Sci., 9: 1164-1172.

Aversa, R., R.V. Petrescu, A. Apicella and F.I.T. Petrescu, 2016n. The basic elements of life's. Am. J. Eng. Applied Sci., 9: 1189-1197.

Aversa, R., F.I.T. Petrescu, R.V. Petrescu and A. Apicella, 2016o. Flexible stem trabecular prostheses. Am. J. Eng. Applied Sci., 9: 1213-1221.

Mirsayar, M.M., V.A. Joneidi, R.V.V. Petrescu, F.I.T. Petrescu and F. Berto, 2017. Extended MTSN criterion for fracture analysis of soda lime glass. Eng. Fracture Mechan., 178: 50-59. DOI: 10.1016/j.engfracmech.2017.04.018

Petrescu, R.V. and F.I. Petrescu, 2013a. Lockheed Martin. 1st Edn., CreateSpace, pp: 114.

Petrescu, R.V. and F.I. Petrescu, 2013b. Northrop. 1st Edn., CreateSpace, pp: 96.

Petrescu, R.V. and F.I. Petrescu, 2013c. The Aviation History or New Aircraft I Color. 1st Edn., CreateSpace, pp: 292.

Petrescu, RV., Petrescu, FIT., 2012a. Northrop. 1st Edn., Books on Demand, ISBN-13: 978-3848209323, pp: 142 .

Petrescu, F.I. and R.V. Petrescu, 2012b. New Aircraft II. 1st Edn., Books On Demand, pp: 138.

Petrescu, F.I. and R.V. Petrescu, 2011. Memories About Flight. 1st Edn., CreateSpace, pp: 652.

Petrescu, F.I.T., 2009. New aircraft. Proceedings of the 3rd International Conference on Computational Mechanics, Oct. 29-30, Brasov, Romania. 